\title{
The Search for Someone to Save: A Defensive Case for the Priority of Secured Credit
}

\section{Rizwaan Jameel Mokal*}

The priority of secured credit has repeatedly and famously been attacked for allowing the exploitation of certain types of unsecured creditor. It has also been blamed for creating inefficiencies. This paper examines these arguments specifically as applied to this jurisdiction, and using both theoretical analysis and recent empirical data, suggests none of them can be sustained. It is argued that security is unlikely to lead to the exploitation of involuntary, 'uninformed', or 'unsophisticated' creditors, since the perverse incentives it allegedly creates for the debtor's management are likely to be outweighed by the managers' liquidation-related costs. It is then pointed out that both exploitation-based and inefficiencybased attack on the priority of secured credit depend on the assumption that secured credit is generally cheaper than unsecured credit, and further, that this is why debtors prefer to borrow on a secured rather than unsecured basis. Recent evidence from this jurisdiction is used to challenge this assumption. This has dramatic implications for the attacks on security, which are discussed. The paper concludes with the demonstration that secured credit, by inducing creditors to lend when they would not do so without being offered priority, is mutually valueenhancing for all types of creditor, including unsecured ones.

1. INTRODUCTION. 1

2. TORT CREDITORS AND THE EXPLOITATION HYPOTHESIS ............................................................ 3

A. Secured Credit and Large Firms ..................................................................................... 4

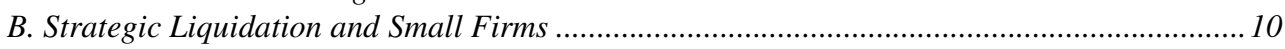

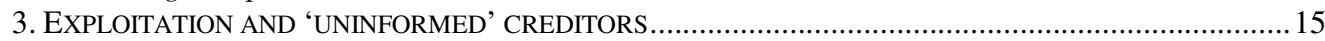

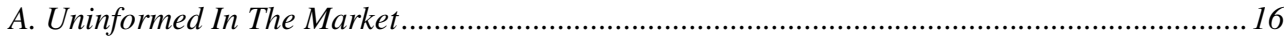

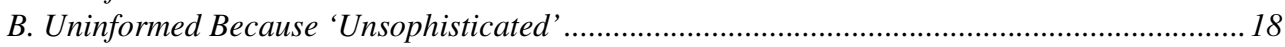

4. 'NON-ADJUSTING' CREDITORS, THE INEFFICIENCY HYPOTHESIS, AND THE RATE REDUCTION

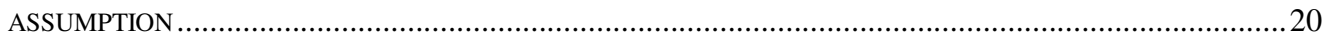

5. INFORMAL 'RESCUES', TRADE CREDITORS AND THE BANK'S SHARE .........................................2 27

6. BEGINNING THE AFFIRMATIVE CASE FOR THE PRIORITY OF SECURED LENDING............................. 30

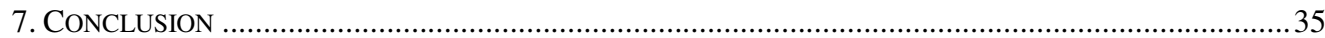

\section{Introduction}

Three characteristics can be said to distinguish the secured from the unsecured creditor. ${ }^{1}$ The secured creditor obtains priority, the right to have the collateral applied to the satisfaction of his debts in a particular order vis-à-vis other creditors. The collateral is also encumbered, in that the debtor loses the right to convey to third parties rights inconsistent with those of the secured creditor. Finally, security provides a remedy in enforcing the secured debt which is quicker and cheaper, hence superior, compared to that afforded to unsecured creditors. It is especially when the debtor is on the brink of or actually in insolvency that the existence of

\footnotetext{
* Reader in Laws, University College London; Research Associate, Centre for Business Research, University of Cambridge; Barrister, 3-4 South Square, Gray's Inn, London. Many thanks to Dan Prentice for his invaluable help, to Michael Bridge, Alison Clarke, Ian Fletcher, Look Chan Ho, Taimur Hyat and the participants of a staff seminar at the UCL Economics Department in Spring Term 2000 for their thoughtful comments. I am particularly grateful to John Armour for saving me from many errors, and for suggestions which improved the arguments here. Nevertheless, the views expressed and all remaining mistakes are mine alone.

${ }^{1}$ LoPucki 'The unsecured creditor's bargain' (1994) 80 Virginia LR 1887, 1921.
} 
security assumes the greatest significance. From the perspective of English (corporate) insolvency law, there is an alternative approach (though a closely linked one) to distinguishing secured from unsecured credit. Secured creditors of a debtor subject to that part of the law are treated differently from its unsecured creditors in two ways. First, the secured creditor stands at the head of the queue for recoupment, from the proceeds of sale of the collateral, of what it is owed. It has priority over other creditors. And second, unsecured creditors lose their ability independently to pursue their claims, and a special collective insolvency regime takes over. ${ }^{2}$ However, secured claimants have immunity from having to participate in this regime, and might for example seize and sell the collateral for the satisfaction of their debt. ${ }^{3}$ Nor is this indulgence towards security holders a relic of the past. A recent study found that secured creditors are treated more favourably in this jurisdiction than in any of the other fourteen OECD countries studied by the authors. ${ }^{4}$

The advantages accorded to the secured creditor have not gone unnoticed. There has always been some feeling -- at least among some academic commentators -- that the balance is tilted too far in favour of those holding security. ${ }^{5}$ The Report of the Insolvency Law Review Committee proposed certain restrictions on the secured creditors' ability to enforce their security. ${ }^{6}$ Famously, it suggested that $10 \%$ of the value of the assets subject to a floating charge be set aside in a company's insolvency for distribution to unsecured creditors. ${ }^{7}$ The ability of secured creditors to appoint a receiver to manage assets subject to their security was also considered, and the Committee proposed a suspension of the security holder's right to enforce that security for twelve months, should a receiver or administrator be appointed. ${ }^{8}$ Neither of these proposals was reflected in the Insolvency Act 1985, enacted in response to the Cork Report. It is the case, however, that preferential creditors rank ahead of the floating charge holder. ${ }^{9}$

In the United States, the late 1970s saw the emergence of a debate on the desirability of the priority scheme enshrined in Article 9 of the Uniform Commercial Code, and how it should be affected by the onset of the debtor's bankruptcy. The ranks of those contributing to the debate have continued to expand, and the literature is now voluminous. ${ }^{10}$ Commentators in this jurisdiction have taken note, and distinguished company and insolvency law scholars have turned their attention to examining the need, role and justifications for secured credit. ${ }^{11}$

\footnotetext{
${ }^{2}$ For an analysis of the collectivity of the liquidation system in England, see eg Mokal 'The Authentic Consent Model: Justifying the collective corporate liquidation regime' [2001] Legal Studies 400; see p 438 for an introduction to the priority/immunity distinction.

${ }^{3}$ Re David Lloyd \& Co. (1877) 6 Ch D 339, 344-5.

${ }^{4}$ La Porta et al 'Law and finance' (1998) 106 (6) J Political Economy 1113.

5 See generally, Goode 'The death of insolvency law', (1980) 1 Company Lawyer 123 and 'Is the law too favourable to secured creditors?' (1983-4) 8 Canadian Business LJ 53.

${ }^{6}$ Insolvency Law and Practice (Cmnd. 8558, 1982), hereafter, 'the Cork Report'.

${ }^{7}$ Ibid, para 1538 et seq.

${ }^{8}$ Ibid, paras 1506-7. The chargee would have had the right to apply to court if the suspension of enforcement rights would prejudice him.

${ }^{9}$ Insolvency Act 1986 (hereafter, 'IA'), s 40(2) and (3) (administrative receivership) and s 175 (liquidation). Schedule 6 of the Act lists the categories of preferential debt. In a recent White Paper called Insolvency - A Second Chance (31 July 2001), the Government proposes to remove from most of those secured creditors who can appoint administrative receivers the right to do so, as well as the right to block the appointment of an administrator.

${ }^{10}$ See the extensive survey in Scott 'The truth about secured financing' (1997) Cornell LR 1436, 1437 fn 1; importantly, see also Schwarcz 'The easy case for the priority of secured claims in bankruptcy' (1997) 47 Duke LJ 425.

${ }^{11}$ See in particular the important papers by Clarke, 'Security interests as property: Re-locating security interests within the property framework', in Harris (ed.), Property Problems from Genes to Pension Funds (1997), and Finch 'Security, insolvency and risk: who pays the price?' (1999) 62 MLR 633, and
} 
A perusal of most recent scholarship here suggests the pendulum has swung from one extreme to the other. In a regime marked by such a tolerant attitude towards the taking of security and its enforcement, security in its present form is now freely condemned as unfair and inefficient. Various proposals to reign in the almighty secured creditor are receiving attention. ${ }^{12}$

That a lot of ink has been spilt on arguing about the proper place of security should be obvious. Numerous useful summaries of the debate so far and of the state of play at present are available. ${ }^{13}$ Yet another summary would add little of value. So this paper assumes some familiarity with the debate, focuses on the position of corporate debtors in this jurisdiction, and argues that the academic pendulum has swung too far. Recall the insolvency-centred classification of the rights of secured claimants given above. This paper addresses itself mainly to issues arising out of the priority of secured claims. It identifies the main lines of attack on the institution of secured credit, and attempts a defence based on empirical and theoretical (and to a lesser extent, doctrinal) grounds.

Some critics of security have argued that it exists mainly to take value away from certain types of unsecured creditor. In particular, debate has centred on the position of various sorts of 'involuntary' creditors. It has also been argued that some 'unsophisticated' creditors are unable to price their loans properly, which allows them to be exploited, through the use of security, by coalitions of debtors and better-informed creditors. Related but distinct are those attacks on the priority of secured credit based not on the exploitation that it allegedly makes possible, but the inefficiency that it supposedly creates. These are also founded on identifying various types of 'non-adjusting' creditor - involuntary, small-claim holders, tax authorities, those who lend before secured credit is issued, etc. Critics argue that secured credit will sometimes be issued, not because it is socially value-maximising, but simply because it allows debtors and some creditors to drain away bankruptcy value from non-adjusting creditors. This leads to various types of inefficiency.

This paper conceive of the attack on the priority of secured credit as a search for someone to save. Critics of security would like to point to a group of creditors who are either harmed by the existence of security, or whose own existence allows security to wreak havoc with social efficiency to the detriment of all. If such a group could be identified, the critics would then be justified in recommending curtailment of (some of) the priority rights of those who offer and accept security. This paper examines the claims that such a group has been found, and finds reason to reject them all. Instead, it reaches the conclusion that the existence of the priority of secured credit is mutually value-enhancing for all those interested in the company's undertaking.

\section{Tort creditors and the Exploitation Hypothesis}

\footnotetext{
the monograph by Milman and Mond, Security and Corporate Rescue (1999). See also Diamond, A Review of Security Interests in Property (1989).

${ }^{12}$ See eg Hudson 'The case against secured lending' (1995) 15 Int Rev of Law and Economics 47, 57 61, and Finch, above n 11 at 651-660.

${ }^{13}$ Particularly good for this purpose are Armour 'Secured credit: A theoretical review' (Unpublished, 1999) and Finch, above n 11.
} 
Here is the basic insight on which the attacks on the priority of secured credit are based. ${ }^{14}$ Consider the world of Debtor, who wishes to borrow from various Creditors. Creditors all start off being equal in every respect (including their share of the Debtor's estate if the latter becomes insolvent). In this world, all Creditors are aware of Debtor's dealings with all other Creditors, and each writes their loan contract with Debtor on the basis of, and relying on, this information. Now if one Creditor (called Bank) demands a security interest and the Debtor complies, all remaining Creditors realise they would have less distributed to them, should Debtor fail (what would have been available for distribution pari passu will first go towards satisfying Bank's debt). But other Creditors are not harmed. They simply raise the interest rates they charge Debtor to compensate for the loss of insolvency value. It follows that, at its worst in this imagined world, security is absolutely harmless.

The assumptions just made are of course unrealistic, and this is what critics of security seize on. That not all creditors would be perfectly informed of their debtor's behaviour, and separately, that not all of them would be able to modify their dealings with the debtor to compensate for the loss in insolvency value, is the basis for almost all the attacks on secured credit. In the real world, critics argue, secured credit can be used to siphon away insolvency value from certain types of unsecured creditor, to the debtor and secured creditors. The argument comes in two varieties, which will be called the Exploitation and the Inefficiency Hypotheses. This Section of this paper, and the next, deal with the first of these. In answering the question why parties sometimes agree to security arrangements, Lynn LoPucki has presented a "promising malignant explanation[] for the existence of secured debt'. ${ }^{15} \mathrm{He}$ argues that 'the deceptive nature of security enables secured creditors and debtors to extract a subsidy from those who involuntarily become unsecured creditors. ${ }^{16}$ A similar subsidy is said to be extracted from 'relatively uninformed unsecured creditors who predictably miscalculate their likelihoods of recovery. ${ }^{17}$ 'The ability to victimize [such] creditors', claims LoPucki, 'may in significant part explain why secured credit is such a widespread phenomenon. 18

\section{A. Secured Credit and Large Firms}

It would be useful to begin with an examination of the facts on which these arguments are based, and of their assumptions. It is important also to keep in mind these arguments were originally made in the US context. The same concerns have recently been voiced in this jurisdiction, notably by Finch in an exhaustive and helpful recent article. ${ }^{19}$ So we might wish to consider whether the differences between the two legal systems have an impact on the transferability of the arguments.

Let us start by identifying the categories of creditor supposedly 'exploited' through the use of security. LoPucki mentions eight such categories, whom he classifies as 'involuntary' or 'reluctant'. ${ }^{20}$ Without wishing to construct watertight categories, perhaps five could be regarded as 'tort' creditors, widely construed. These include product liability claimants, victims of business torts ('ranging from negligence to intentional interference with

\footnotetext{
${ }^{14}$ See eg Bebchuk and Fried 'The uneasy case for the priority of secured claims in bankruptcy' (1996) 105 Yale LJ 857, 881-2, and Hudson, above n 12 at 48.

${ }^{15}$ Above $\mathrm{n} 1$ at 1895 .

${ }^{16}$ Ibid at 1891.

${ }^{17}$ Ibid. This is the subject of the next Section.

${ }^{18}$ Ibid at 1897 (footnote omitted).

${ }^{19}$ In Finch, above n 11.

${ }^{20}$ LoPucki, above n 1 at 1896-7; the latter term comes from Sullivan et al, As We Forgive Our Debtors (1989).
} 
contractual relations'), victims of antitrust violations, unfair competition, patent, trademark and copyright infringement, environmental agencies which perform clean-ups, and creditors who acquire that status because of the debtor's fraud. The remaining categories consist of tax authorities and certain other government agencies, and utility companies. These are all to be considered 'involuntary', argues LoPucki, since they are 'not in the business of extending credit and $[\mathrm{do}]$ not seek credit relationships. ${ }^{21}$

LoPucki claims that "Any debtor who either has, or expects in the future to have, involuntary unsecured creditors will find economic advantage in "selling" secured status to its voluntary creditors. ${ }^{22} \mathrm{He}$ explains that to the extent that the debtor's capital structure consists of equity, its shareholders are exposed to liability. Claims against the firm by involuntary creditors would be met out of the firm's assets. This reduces the firm's value and therefore directly hurts shareholders, the only other claimants to those assets. The existence of debt in the firm's capital structure reduces shareholders' 'real exposure' to that liability. 'Real exposure' is that part of its tort liability that the debtor is forced to pay, rather than being able to defeat through declaring bankruptcy. So once debt has been issued, some of the firm's value comes from creditors, and some of the involuntary claims would be met from that value. This line of reasoning indicates that the shareholders' real exposure to tort liability is 'almost eliminated' once all of the tortfeasor's assets, including its future stream of income, have been fully encumbered. Should involuntary claims now arise, and should shareholders wish the firm to avoid having to repay them, the firm can declare insolvency and shareholders can walk away without further liability to anyone. ${ }^{23}$

The simple example used by LoPucki illustrates nicely how the argument is supposed to work. ${ }^{24} \mathrm{D}$ has assets of $\$ 100$ and owes $\mathrm{C}$ a debt of $\$ 100$. D's activities then tortiously cause $\mathrm{T}$ an injury of $\$ 100$, without thereby gaining $\mathrm{D}$ anything in return. $\mathrm{D}$ is subsequently liquidated with $\$ 100$ of assets and $\$ 200$ of debt. If $C$ is unsecured, both it and $\mathrm{T}$ will receive $\$ 50$ each. If $\mathrm{C}$ is secured, it receives everything, and $\mathrm{T}$ gets nothing. So $\mathrm{D}$ obviously has an incentive before the liquidation (for businesses expected to inflict such injuries, perhaps well before it) to offer $\mathrm{C}$ security. This is because $\mathrm{C}$ in return will offer a decrease in its interest charges to reflect the reduced risk of being left with less than full payment in D's insolvency. Tort victim $\mathrm{T}$, being an involuntary creditor, cannot of course raise its interest rates to compensate. So D pockets the difference. This subsidy, caused by the "externalization of tort risk' onto T, creates incentives for firms to undertake more risk-laden projects. ${ }^{25}$ This will happen not because those projects are socially efficient, but simply because some of their costs are shifted onto involuntary third parties while the benefits go only to the tortfeasor's shareholders.

It seems clear the 'involuntary' creditors who really concern LoPucki are tort victims ${ }^{26}$ The example reproduced above, and the supporting literature he refers to ${ }^{27}$ as well as most of his discussion, all are concerned overwhelmingly with tort liability. Further, the main thrust of his argument is that security allows additional 'risk' (meaning here the

\footnotetext{
${ }^{21}$ LoPucki, above $\mathrm{n} 1$ at 1896-7 (footnote omitted).

${ }^{22}$ Ibid at 1898.

${ }^{23}$ Ibid at 1898-9, including fn 48.

${ }^{24}$ Ibid at 1898.

${ }^{25}$ Ibid, quoting David Leebron 'Limited liability, tort victims, and creditors' (1991) Columbia LR 1565, 1648 .

${ }^{26}$ This point has been noted before; see Block-Lieb 'The unsecured creditor's bargain: A reply' (1994) 80 Virginia LR 1989, 1993, and Knippenberg 'The unsecured creditor's bargain: An essay in reply, reprisal, or support?' (1994) 80 Virginia LR 1967, 1969-70 fn 13.

${ }^{27}$ Apart from Leebron's article, see also the literature mentioned in LoPucki, above n 1, fnn 36, 47, 51, $54,57,58,62,65,70,81,82,88$, etc.
} 
potential to cause tortious harm) to be created and externalised. This would generally describe the undertaking of riskier projects which would not otherwise have been undertaken, or projects which -- in the absence of secured creditors' priority over 'involuntary' ones -would have been executed in a less risky way, i.e. by employing more (costly) precautions. 'Involuntary' liabilities which arise regardless of the riskiness of the company's activities, e.g. utility bills and taxes, would not in most cases be covered by this line of argument. For this reason, the treatment here of the Exploitation Hypothesis focuses on tort creditors (construed broadly, as above) ${ }^{28}$

How, then, should LoPucki's argument be evaluated? The charge is of course a serious one: that some (perhaps most) debtors who issue security do so in order to profit from inflicting uncompensated harm on others. To put into context the magnitude of this assertion, in the US, domestic borrowers alone are estimated to have about two trillion dollars of secured debt. ${ }^{29}$ Finch, who (as mentioned) has deployed LoPucki's argument in relation to secured credit in England and regards it as part of "the core objection to the provision of security', ${ }^{30}$ asserts that 'Security taking is the norm in relation to most borrowings' ${ }^{31}$ So English debtors too must be 'victimizing' tort creditors on a massive scale. ${ }^{32}$ Keeping in mind the gravity of this objection to security, we should perhaps begin by asking what evidence is presented in its support.

Citing US research which is supposed to have found twenty-three percent of the unsecured debt of consumer bankrupts to be owed to 'reluctant' creditors, ${ }^{33}$ LoPucki 'speculate[s] that money owed to reluctant creditors constitutes an even larger portion of the debt of financially distressed companies. ${ }^{, 34}$ In support, he states that in a study of 'the 43 largest reorganizations of the 1980s' (hereafter, the LoPucki-Whitford study), it was found that for two of the companies studied, more than two-thirds of the unsecured debt was 'involuntary'. These were Johns-Manville Corporation, 'with well in excess of $\$ 2$ billion in asbestos personal injury claims alone', and Smith International, which had 'a \$205 million judgment against it for patent infringement. ${ }^{35}$ Further, in 'at least 7 more of [the] 43 companies, management had fraudulently concealed the financial problems of the company in the period before bankruptcy, casting doubt on whether any of their unsecured creditors should be considered to have consented to the status they were given'. So overall and importantly, 'in nearly a third of the cases [] studied, substantial portions of the unsecured debt were held by creditors who had not meaningfully agreed to their status as such. ${ }^{36}$

\footnotetext{
${ }^{28}$ The rest are considered in Sections 4 and 5 of this paper.

${ }^{29}$ Mann 'Explaining the pattern of secured credit (1997) 110 Harvard LR 625, 627, including fn 1.

${ }^{30}$ Reading what here has been called the Exploitation Hypothesis together with the Inefficiency one; see eg Finch, above n 11, at 644 (first paragraph), 645 (bottom of the page, running over to 646), etc. ${ }^{31}$ Ibid at 634 .

${ }^{32}$ Ibid at 646 (first full paragraph), arguing that security leads to excessive risk-taking, the costs of which are then externalised onto unsecured creditors. However, it is not clear whether the reference to 'risk' here indicates a higher probability of insolvency, or a greater potential to inflict tortious harm.

${ }^{33}$ Sullivan et al, above n 20 at 294.

${ }^{34}$ LoPucki, above $\mathrm{n} 1$ at 1896.

${ }^{35}$ Ibid, fn 41, citing LoPucki and Whitford 'Corporate governance in the bankruptcy reorganization of large, publicly held companies' (1993) 141 U Pa LR 669, 738, including fnn 226-7. Two other companies not included in that study are also mentioned: Texaco, Inc. with an $\$ 11.1$ billion tort judgment against it, and $\mathrm{A}$. H. Robins, with $\$ 2.5$ billion in tort claims.

${ }^{36}$ LoPucki, above n 1 at 1896-7, fn 41 (these included non-tort 'involuntary' creditors). LoPucki again returns to the examples mentioned above (Johns-Manville and Texaco) to derive support for the proposition that large US corporations are underinsured for certain types of tort liability; see ibid at 1906, fn 81.
} 
It would not be unfair to say this demonstration that corporate debtors engaged in formal bankruptcy proceedings have substantial 'involuntary' unsecured liabilities has entered the mythology of those supporting restrictions on secured credit. Apart from LoPucki himself, it is cited by Bebchuk and Fried (hereafter, 'Bebchuk-Fried') as part of their attack on security. ${ }^{37}$ Finch cites it no less than five times. ${ }^{38}$ Even those who are generally supportive of the priority of secured credit have been known to refer to it as indicating the possible malignant effects of security. ${ }^{39}$ No other evidence seems to be available to show that (especially in this jurisdiction) there are significant tort claims against companies in financial distress. As it is, the LoPucki-Whitford study has been used to back up all manner of proposals to cut down on the rights of secured creditors on both sides of the Atlantic. ${ }^{40}$ And in particular, it has widely been taken as proof that the ability of debtors to transfer value from 'involuntary' to secured creditors is in fact encouraging excessive amounts of corporate risk-taking and an unacceptable degree of uncompensated harm (including tortious harm).

Things, however, are not as they seem. The LoPucki-Whitford study, far from providing any support for the Exploitation Hypothesis, in fact goes some way towards disproving it. Let us begin by noting that the study focused on the 'largest reorganizations of the 1980s'. ${ }^{41}$ It follows that each of the 43 companies studied had extensive business interests, and correspondingly, the capacity to incur substantial 'involuntary' debts. Save in the most exceptional circumstances, smaller companies simply would not have the ability (say) to inflict 'well in excess of $\$ 2$ billion' of personal injuries, or face realistic claims of $\$ 205$ million for patent infringement. ${ }^{42}$ The reader can be forgiven for thinking that to point this out is to state what is blatantly obvious. But here lies the problem for LoPucki's thesis. It is universally acknowledged (even by critics of security) that the larger the company, the more unlikely it is to issue secured debt.

Here is some of the evidence. Bebchuk-Fried themselves have stated that 'In the United States, large, publicly traded firms tend not to borrow on a secured basis' and that 'most commercial secured debt [] is issued by small- and medium-sized companies. ${ }^{43}$ Ronald Mann calls it 'the most well-established aspect of [the] actual practice' of lending that 'the strongest companies in our economy ordinarily do not secure their debts. ${ }^{44}$ Steven Schwarcz found in an analysis of fourteen investment grade public companies selected at random that 'with extremely limited exceptions, only their non-recourse debt is secured.' He concluded that his research, though based on a small sample, '[did] suggest that investment grade companies have little or no secured debt and little non-recourse debt. ${ }^{45}$ This is strongly supported by UK evidence. Ameziane Lasfer's study of all the companies quoted on the London Stock Exchange in the 1984-96 period (for which the relevant data was available in

\footnotetext{
${ }^{37}$ See eg above n 14 at 883 , fn 89 : noting that 'while uninsured tort claims do not surface often in bankruptcy, when they do turn up, they can be substantial.' They cite it again in Bebchuk and Fried 'The uneasy case for the priority of secured claims in bankruptcy: Further thoughts and a reply to critics (1997) 82 Cornell LR 1279, 1296-7, fn 60.

${ }^{38}$ Finch, above n 11, at 645 fn 80, 655 fn 138, 661 (twice) fnn 167 and 170, and indirectly at 644 fn 73.

${ }^{39}$ As examples, see Scott, above n 10 at 1459 fn 54, and White 'Failure and Forgiveness: A review', (1999) 73 American Bankruptcy LJ 435, 443 fn 36.

${ }^{40}$ See the sources mentioned above.

${ }^{41}$ LoPucki, above n 1 at 1897 fn 41 (emphasis added).

${ }^{42}$ Ibid.

${ }^{43}$ Above n 14 at 859-60 (citing Booth 'Contract costs, bank loans, and the cross-monitoring hypothesis' (1992) J Fin. Econ 25, 40 fn 10), and 924, respectively.

${ }^{44}$ Mann, above $\mathrm{n} 29$ at 629-30 fn 15, and the sources therein cited.

${ }^{45}$ Above $\mathrm{n} 10$ at $446 \mathrm{fn} 91$. For further evidence that the size of the firm and the incidence of secured debt are inversely related, see Barclay and Smith 'The priority structure of corporate liabilities' (1995) $50 \mathrm{~J}$ Finance 899, 912, and Boot et al 'Secured lending and default risk: Equilibrium analysis, policy implications and empirical results' (1991) 101 Econ J 458, 470-1.
} 
machine-readable form) showed that "secured debt is negatively related to firm size; small firms hold more than three times [the amount of] secured debt than do larger companies. The proportion of small companies' debt that is secured is $61 \%$, while that of the larger companies is $17 \% . " 46$

Perhaps most interestingly, the LoPucki-Whitford study, on which most of the Exploitation Hypothesis is based ${ }^{47}$ itself found that 'many of [the large companies studied] issued little or no secured debt, even as they approached bankruptcy reorganization. ${ }^{48}$ In particular, Johns-Manville Corporation, which LoPucki had earlier mentioned as a particularly good case in support of the Hypothesis because it had tort debts 'well in excess of $\$ 2$ billion' and insufficient insurance cover (of 'only approximately $\$ 700$ million') ${ }^{49}$, also 'had assets of $\$ 2.2$ billion... and secured debt of approximately $\$ 40$ million'. ${ }^{50}$ Smith International, the only other company mentioned in the study as having a huge tort judgment against it, actually paid 107.1 cents on the dollar to its unsecured creditors. ${ }^{51}$ Nor were these cases exceptional. LoPucki blandly states that 'Liquidations of [many of the] companies [in the sample], even in bankruptcy, would yield substantial recoveries for unsecured creditors. ${ }^{52}$ He notes that:

In 28 of the 42 cases $(67 \%)$ in which the debtor had bank debt, the primary banks were wholly or substantially unsecured as bankruptcy approached. The banks demanded security in at least 20 of the 28 cases (71\%). The debtor refused to grant security in 10 of the 20 cases (50\%). In five of the 10 cases in which security was granted shortly before bankruptcy, the bankruptcy was filed within the 90-day preferences period and the grant was attacked. [In fact], it would appear that companies are more likely to grant security when they avoid bankruptcy. ${ }^{53}$

\footnotetext{
${ }^{46}$ Lasfer, 'Debt structure, agency costs and firm's size: An empirial investigation' (24 November 1999), available at URL: <http://www.business.city.ac.uk/af/wopapers/mez/debtStructure.pdf>.

${ }^{47}$ As are important parts of Bebchuk-Fried's and Finch's attacks on security; see above.

${ }^{48}$ LoPucki, above $n 1$ at 1924-5 (emphasis added), including fnn 145-6.

${ }^{49}$ Ibid at 1906 fn 81 .

${ }^{50}$ Ibid at 1924-5 fn 145. The reader is left to do the sums.

${ }^{51}$ This company was in fact solvent! See LoPucki and Whitford, 'Bargaining over equity's share in the bankruptcy reorganization of large, publicly held companies' (1990) 139 U. Penn. LR 125, 176 Table IV(B). All the figures given by LoPucki as supporting the Exploitation Hypothesis must be treated cautiously. For example, the only other companies mentioned by name as having "substantial "reluctant unsecured debt", are Baldwin-United, Charter Company, McLouth Steel Corporation, and Braniff (above $\mathrm{n} 1$ at 1896-7, fn 41). As it happens, Baldwin-United paid 54.3 cents on the dollar to unsecured creditors, and Charter was actually solvent, its unsecured creditors bargaining to accept 86.3 cents on the dollar in breach of the 'absolute priority rule'. Only McLouth's and Braniff's unsecured creditors fared less well, getting 18.2 cents and 4.9 cents for every dollar of their claims respectively (LoPuckiWhitford, 'Bargaining', pp. 166-7, including Table IV(A), and p. 142, Table III). Note also that Texaco, Inc., which LoPucki mentions, above n 1 at 1896-7 fn 41 as not included in the original study but as bolstering his argument since it had an '\$11.1 billion tort judgment' against it, actually settled for $\$ 3$ billion. What is more relevant, the alleged tort there had been committed, not against someone vulnerable whom one might think critics of security were concerned to protect, but against the multibillion dollar giant Pennzoil, which could be expected to look after itself; see e.g. David Cutler and Lawrence Summers 'The costs of conflict resolution and financial distress: Evidence from the TexacoPennzoil litigation' (1988) 19 Rand J. Economics 157. Again, the invocation of this and any similar cases in support of the Exploitation Hypothesis seems inappropriate.

${ }^{52}$ LoPucki, above $n 1$ at 1924-5, noting at fn 146, eg, that 'In at least five cases in which the debtor did not liquidate, the liquidation value of the assets exceeded the secured debt by a sufficient amount that it was clear beyond argument that unsecured creditors would have substantial recoveries in liquidation.'

${ }^{53}$ LoPucki, above n 1 at 1927 fn 153 (emphasis added).
} 
Further, of the seven companies whose unsecured creditors are regarded as 'reluctant' by LoPucki because they might have made their loans on the basis of fraudulent information provided by the debtor's management, or the fraudulent concealment of information by it, two were solvent. ${ }^{54}$ The creditors of three others could expect 'substantial' recoveries from claims pursued by the debtor's replacement management against its displaced one, or because the latter settled the administrative charges brought against them by the SEC, or both. ${ }^{55}$ So not only do we have no indication that these seven companies had issued substantial secured debt, there were, in addition, significant recoveries by the unsecured creditors of five of them in any case.

We should note the significance of this analysis. As mentioned, these are the very companies whose conditions have repeatedly been used to support versions of the Exploitation Hypothesis. These are also par excellence instances where (if the Hypothesis held, so that the existence of security is to be explained by virtue of its ability to shift costs onto 'involuntary' or 'reluctant' creditors) the managers and shareholders of these large firms would have the greatest incentive to issue secured debt, since they would have massive tort and other 'involuntary' liabilities to externalise. And yet secured borrowings were relatively minuscule and there were actually sufficient assets available to meet much of those liabilities. Secured debt was not then being used to externalise costs, nor were 'involuntary' creditors (of whatever description) being 'victimized'. It must therefore be reasonable to conclude that the LoPucki-Whitford study provides no support at all for the Exploitation Hypothesis.

Further and importantly, we must note the differences between the US legal system, where LoPucki-Whitford's data originates, and that prevalent in this jurisdiction, where, as noted above, it has recently been used as a basis for some arguments about secured credit. For the LoPucki-Whitford study, in cases where some of the management of the debtor was implicated in fraud, the authors themselves note that the US Bankruptcy Code Chapter 11 'reorganization procedure sometimes enables managers to escape liability for their wrongdoing', since the entrenchment of existing management brought about by that procedure 'gives even badly tainted managers leverage to negotiate their exit'. The managers may be able to employ this leverage to demand 'a release of liability', or to 'hinder[] or delay[] actions by defrauded creditors and shareholders' ${ }^{56}$ In this jurisdiction, by contrast, the 'existing management out' response of formal insolvency procedures makes such activity much more unlikely. To the extent that the knowledge that, should their firm enter a formal proceeding, they would necessarily be displaced by an independent party, feeds into the decision-making of managers ex ante, they have a stronger incentive (compared to their US counterparts) not to engage in such activities in the first place. This weakens even further whatever force LoPucki's arguments might have in the US context.

\footnotetext{
${ }^{54}$ AM International and Penn-Dixie; see LoPucki and Whitford 'Corporate governance in the bankruptcy reorganization of large, publicly held companies' (1993) 141 U Pennsylvania LR 669, 738, fnn 226-7, and LoPucki-Whitford, above n 51 at 166, Table IV(A).

${ }^{55}$ LoPucki-Whitford, above n 54 at 738-9, including fnn 227-8. One of these companies was EPIC; accurate information about the expected total dividend paid to its unsecured creditors was not available; LoPucki-Whitford, above n 51 at 141 fn 33. So their total recoveries may or may not have been even greater than the 'significant' damages won on their (and the other claimants') behalf by the replacement management. Of the remaining three, for two companies, Technical Equities and Baldwin-United, taking into account both the proceeds of the actions against the debtors' displaced management and dividends from reorganisation, their unsecured creditors recovered in excess of 50 cents on the dollar on their outstanding debts against the insolvent debtor; see ibid at 142 Table III. The value of the settlement in case of the third, Nucorp, was $\$ 41 \mathrm{~m}$, and this went to the shareholders, the plaintiffs in the class action there; see LoPucki-Whitford, above n 54 at 738 fn 227.

${ }^{56}$ Ibid at 739-40, including fnn 229-32.
} 


\section{B. Strategic Liquidation and Small Firms}

Suppose now that the defender of the Hypothesis were to concede that large companies do not generally issue secured debt, so the Hypothesis does not apply to them. But it could still apply to smaller firms, who might well have resorted to significant amounts of secured credit. Their motivation might be to 'sell' the insolvency share of tort creditors to others by issuing security. However, this suggestion seems to have its own problems. We should recall that the Hypothesis turns on the ability of shareholders to reduce their 'real exposure' to tort liability etc. It would be no good engaging in excessively risky activities and acquiring a reduction in the price of credit by issuing security, only to have the savings paid out as compensation to all those affected by the excessive risks taken. So for the argument to work, it must be possible 'to defeat [the liability] through insolvency or bankruptcy': ${ }^{57}$

To freeze out their involuntary creditors, firms would have to incur secured debt to the liquidation value of their assets and be willing to go through some kind of liquidation if the involuntary creditors refused to settle. ${ }^{58}$

A firm must be willing to liquidate in order to nullify its tort liability by means of an all-secured debt capital structure. ${ }^{59}$

However, for smaller firms, especially those which have operated sufficiently long and widely to have incurred significant 'involuntary' (in particular, tort) liabilities, the costs to the firm's decision-makers associated with liquidating it are likely to be significant. The managers of smaller firms, especially those becoming subject to insolvency proceedings in this country, are very likely to have a substantial equity stake in their company. ${ }^{60}$ Such shareholder-managers would also have firm-specific skills and idiosyncratic value invested in it. ${ }^{61}$ Very frequently, they would have guaranteed some of their company's debt, ${ }^{62}$ and many would also have lent it significant amounts. ${ }^{63}$ So a significant proportion of their wealth, material and non-pecuniary, is likely to be invested in the firm, and this investment will be undiversified. For this reason, far from being all too ready to liquidate them strategically, shareholder-managers 'can be expected to fight [] single-mindedly to keep [them] afloat. ${ }^{64}$ It

\footnotetext{
${ }^{57}$ LoPucki, above $\mathrm{n} 1$ at 1898, including fn 48.

${ }^{58}$ Ibid at 1903.

${ }^{59}$ Ibid at 1905 fn 77.

${ }^{60}$ There is evidence that only $2 \%$ of the companies engaged in an insolvency procedure were quoted on a recognised stock exchange, no share capital was held by institutional investors in $93 \%$ of the cases, and in only $2 \%$ of such proceedings had the insolvent firm benefited from a rights issue or other equity investment in the 12 months leading up to the insolvency proceedings; see the Association of Business Recovery Professionals (or ABRP; formerly, SPI), Survey of Business Recovery in the UK: 9th. Survey (2001), p. 12. So most such firms are closely-held.

${ }^{61}$ See eg Jackson and Scott 'On the nature of bankruptcy: An essay on bankruptcy sharing and the creditors' bargain' (1989) 75 Virginia LR 155, 174.

${ }^{62}$ This point is absolutely crucial, and is discussed below.

${ }^{63}$ Franks and Sussman, The Cycle of Corporate Distress, Rescue and Dissolution: A Study of Small and Medium Size UK Companies, IFA Working Paper 306 (April 2000), in their study of firms in the 'business support units' of three large UK clearing banks, found that for the firms in their sample, shareholder-directors were owed an average (for the three banks respectively) of $6.1 \%, 2.5 \%$ and $2.4 \%$ of the total debt outstanding. The authors note that 'Although owners' loans are a small percentage of the total debt, in absolute size they may be significant for the owner.' See pp 7-8, including Table 3. This is of course to be added to their massive equity stake in the firm (most such firms being closelyheld), and to their exposure to the firm's losses as guarantors of its loans, to get a fairer picture of the pecuniary costs of liquidation to them.

${ }^{64}$ Mokal 'An agency cost analysis of the wrongful trading provisions' [2000] CLJ 335, 353-354.
} 
should be clear the (non-legal) costs of liquidation to them are likely in most cases to be very high indeed.

Consider also the differences in the legal context in which the Exploitation Hypothesis was originally expounded, and here in England where it is now being deployed. One significant difference is the 'existing management out' approach of English insolvency law, which stands in stark contrast to Chapter 11 of the US Bankruptcy Code. Chapter 11 perversely "provides a vehicle for a liquidation that can discharge unsecured creditors even while the owner-managers retain control. ${ }^{65}$ If that were not enough, bankruptcy courts frequently allow the 'absolute priority rule' (requiring senior claimants to be fully paid off before junior classes receive anything) to be breached in return for 'new value', so that shareholder-managers may retain an equity interest even though creditors are not fully paid. ${ }^{66}$ So the costs to 'owner'-managers of 'liquidation' in the US, in terms of equity interest, job security and firm-specific human capital, are noticeably lower than in England ${ }^{67}$ In addition, LoPucki states that tort creditors may have little protection from the law if 'an initially adequately capitalized corporation [] sank into insolvency and continued to operate in that condition' merely on the basis of the gain derived from externalising tort liability. ${ }^{68}$ Here, of course, directors would be under the obligation, once there remained no reasonable prospect of avoiding insolvent liquidation, to take all the steps they reasonably ought to, to minimise harm to unsecured creditors. Any default on this obligation could be punished by an award of personal liability against them. ${ }^{69}$ Yet another difference lies in the attitude of the two jurisdictions towards the granting of security to cover antecedent debts, another step in the process through which (LoPucki maintains) tort risks can be externalised: 'Granting security for an antecedent debt will never run afoul of [the relevant fraudulent transfer] provision because... value is given if an antecedent debt is secured' ${ }^{70}$ In England, this would be liable to be challenged as a voidable preference by the liquidator. ${ }^{71}$ With respect, these differences between the two jurisdictions may not have received the attention they deserve from those attempting to transplant the Exploitation Hypothesis to this country.

Consider the implications of the points just made. All the costs mentioned above (legal and otherwise) must be weighed in the scales against the benefits to be derived from liquidating a company in order to externalise tort and other liabilities. For smaller companies (i.e. most of those likely to become subject to insolvency law), the costs are significant, as already noted. Their shareholder-managers would lose their jobs, their equity stake, and

\footnotetext{
${ }^{65}$ LoPucki, above n 1 at 1903 (footnote omitted), explaining a crucial step in his argument. On this point, see Armour, Cheffins and Skeel, 'Corporate Ownership Structure and the Evolution of Bankruptcy Law: Lessons from the UK' [2002] Vanderbilt LR (forthcoming).

${ }^{66}$ See eg Weiss 'Bankruptcy resolution: Direct costs and violation of priority of claims' (1990) $27 \mathrm{~J}$ Financial Economics 285, though noting that this might happen much more frequently in larger than smaller firms, and might be more common in some US jurisdictions than others.

${ }^{67}$ This should be read subject to the observation that these differences have been decreasing since LoPucki's article was published, both because US law has become tougher on the managers of small firms, and because English law might be becoming marginally more lenient; see Armour et al, above n 65.

${ }^{68}$ LoPucki, above $\mathrm{n} 1$ at 1904, in the context of the doctrine of piercing the corporate veil.

${ }^{69}$ IA, s 214; Mokal, above n 62 at 364-5, runs through this argument in detail.

${ }^{70}$ LoPucki, above n 1 at 1905 fn 76. LoPucki focuses on the Uniform Fraudulent Transfer Act on this point, rather than on the preference avoidance provisions (s 547) of the Bankruptcy Code, which would catch the grant of security; see e.g. In re Lawson 122 F.3d 1237 (1997). This is perhaps because of the restrictive 90-day 'twilight' period within which security must be granted before the onset of bankruptcy, if it is to be caught by s 547 .

${ }^{71}$ IA, s 239; see also IA, s 245 (floating charge to secure past indebtedness).
} 
substantial undiversified firm-specific wealth. ${ }^{72}$ They might also become subject to legal liability. Creditors who accept security in such circumstances might face the possibility of having the objectionable transactions reversed. So the expected benefits from the externalisation of tort risks etc. would have to be very substantial to outweigh the expected costs. However, as already noted, smaller firms are unlikely to be able to operate on a scale large enough to incur extensive involuntary debts. ${ }^{73}$ Now recall that the benefits of risk externalisation are supposed to arise from the reduction in interest rates on secured loans. ${ }^{74}$ These 'subsidies' are likely to be very small in comparison with the costs of liquidation.

To illustrate this point, here is a simple example to work through. Given that most firms have less than $£ 1$ million of total liabilities when they become subject to insolvency proceedings, give LoPucki the benefit of the doubt by assuming a fairly large secured loan from Lender to Debtor which will stand at $£ 500,000$ at the time of liquidation. ${ }^{75}$ Now banks do not lend at all, secured or unsecured, at rates $7.5 \%$ over base rate. ${ }^{76}$ Let the base rate be $8 \%$. Assume that without security, Debtor would only be able to borrow at the rate of $15 \%$ (i.e. at about the limit beyond which banks refuse to lend) because of the riskiness of its proposed project, but with security, the rate falls incredibly to $10 \%$ (this again gives LoPucki benefit of the doubt by maximising the interest rate benefit of security). ${ }^{77}$ Debtor is to remain in business for ten years before liquidating. ${ }^{78}$ This gives a generously long period for the objectionable 'subsidy' to continue and allows for plenty of 'involuntary' debts to be accumulated. Note though that almost inevitably, this also increases the costs of liquidation in terms of the shareholder-manager's human capital and idiosyncratic investments. Lender lends in four equal instalments at 2.5 year intervals starting in the first year, and let us assume (in LoPucki's favour) that the whole of the capital is outstanding at the end of the period. The total 'subsidy' is therefore $£ 156,250 .{ }^{79}$ This figure is by no means negligible, even if the 'saving' accrues over ten years. In return for this sum, however, which results from stated and un-stated assumptions incredibly favourable to his thesis, LoPucki's argument requires the shareholder-manager to incur tort debts and then liquidate his firm, thereby losing material and non-pecuniary investments worth a decade of his life and risking legal liability. In light of this example, ${ }^{80}$ it is fairly certain that for shareholder-managers of smaller firms,

\footnotetext{
${ }^{72}$ This argument may not apply when what is liquidated is a subsidiary company. However, remember that what is being challenged here is the claim that the Exploitation Hypothesis explains the ubiquity of secured credit, that the type of company which most often borrow secured and most often become insolvent are SME's, and that there are unlikely to be many SME's whose corporate and debt structures render them tort judgment proof in this way. At the very least, no evidence to this effect is provided by the critics of security.

${ }^{73}$ In fact, an overwhelming number of firms in insolvency proceedings (81\%) have liabilities less than $£ 1$ million, and less than 5\% have liabilities of more than $£ 5$ million; see SPI, Survey of Company Insolvency: 8th. Survey (1999), p. 7.

${ }^{74}$ This crucial issue of the relationship between secured credit and interest rates is taken up in Section 4 , below.

${ }^{75}$ Overall, average individual debts range from $£ 6,000$ among property companies to $£ 484,000$ in construction; SPI, above $\mathrm{n} 73$ at 9.

${ }^{76}$ Bank of England, Finance for Small Firms: A Seventh Report, January 2000, p. 19. The explanation for this ceiling is probably that high rates invite adverse selection and create moral hazard; see below.

${ }^{77}$ The mean margin over base rate for banks was 3.4\% in the first half of 1999; see ibid at 19. For firms in financial distress, one important recent study found the interest rate spread was less than 4\%; see Franks and Sussman, above n 63 at 13 Table 8, and 19 Table 10a (this study is discussed in greater detail below). In our example, the margin is a low $2 \%$ after security is given.

${ }^{78} 74 \%$ of firms in insolvency proceedings are ten years of age or less; SPI, above $\mathrm{n} 73$ at 8 .

${ }^{79}(5 \% \times 125,000 \times 10)+(5 \% \times 125,000 \times 7.5)+(5 \% \times 125,000 \times 5)+(5 \% \times 125,000 \times 2.5)$.

${ }^{80}$ The reader is invited to modify the figures to identify the parameters within which the benefits of the 'subsidy' intuitively seem to outweigh the costs of liquidation to shareholder-managers. The author makes the statement to which this note is attached after having performed this exercise.
} 
externalisation-motivated liquidation would very rarely (if ever at all) be a viable proposition. ${ }^{81}$

Here, then, are the reasons why LoPucki's arguments apply to a null set. Large firms with potentially a large number of involuntary creditors do not give security even when facing very extensive such liabilities, and mostly end up paying those debts. Smaller firms, which do issue secured debt and which constitute an overwhelming proportion of the subjects of insolvency law, do not ordinarily have the capacity to incur involuntary debts large enough to render attractive any externalisation-motivated attempt to liquidate. The Exploitation Hypothesis is therefore left with no part of the corporate world to which to apply. Therefore, it certainly does not explain "why secured credit is such a widespread phenomenon. ${ }^{, 82}$ And because of the differences in the two legal systems, this is even truer here than in the US. ${ }^{83}$

What about evidence? We can to a certain extent test the Hypothesis using empirical data from this jurisdiction. LoPucki would explain the pattern by which security becomes widely-employed by asserting that $[A]$ firms would reduce equity in their capital structure, $[B]$ create large amounts of tort liability, $[C]$ 'incur secured debt to the liquidation value of their assets', and then $[D]$ undergo an insolvent liquidation. ${ }^{84}$ As more and more firms discovered this easy way of making a profit, $[E]$ the trend would be for firms to be increasingly tort judgment-proof:

Equilibrium would be an all-secured debt capital structure because real tort exposure would be zero. Any change in that capital structure would increase real tort exposure. Reputational concerns would tend to disappear in the intense competition of a world where transaction costs are small. ${ }^{85}$

But for small firms, which are the most likely to be liquidated insolvent, the trend is actually towards more equity and more internal finance in the firm's capital structure (therefore, more real exposure to tort liability). In the 1987-90 period, 65\% of small businesses sought external financing of whatever type. In 1995-97, this figure had fallen dramatically to only $39 \%{ }^{86}$ Since equity is (and even more strongly, shareholder-managers' own funds are) not being reduced as a proportion of small firm capital structure, and since the trend is in the opposite direction, Propositions $A$ and $E$ are false. Further, according to the Hypothesis, it would be clearly more rewarding for businesses to shut down only once a substantial number of 'involuntary' (especially tort) claimants had been swept up in its liability net and the firm

\footnotetext{
${ }^{81}$ LoPucki, above $\mathrm{n} 1$ at 1905, fn 77, makes the following concession: The reason why most firms today are not tort-judgment proof is because 'The transaction costs of liquidation [even under the lax US regime] may exceed the benefit to be gained by escaping tort liability.' It is submitted that they almost always will, for all firms except those on the larger end of the spectrum (which rarely borrow secured). That LoPucki's argument seems mainly to apply only to larger firms has been noted by one of LoPucki's American critics; White 'Corporate judgment proofing: A response to Lynn LoPucki's 'The death of liability', (1998) 107 Yale LJ 1363 ('Professor LoPucki is concerned principally, if not exclusively, with the tort and statutory liabilities of public commercial firms'). See also LoPucki, above $\mathrm{n} 1$ at $1905 \mathrm{fn}$ 78, on the existence of reputational costs.

${ }^{82}$ LoPucki, above $\mathrm{n} 1$ at 1897 (footnote omitted).

${ }^{83}$ Even in the US, LoPucki's views are unlikely to be persuasive; see eg White, above n 81 at 1364 , who (in response to a later and broader version of the argument being considered here) examines empirical evidence to conclude that 'the story Professor LoPucki tells [about companies designing their capital structure so as to be able to defeat certain types of liability] is fictional'; and Schwarcz 'The inherent irrationality of judgment proofing' (1999) 52 Stanford LR 1, 51, who concludes that 'The claim that innovative business transactions will kill liability is simply wrong.'

${ }^{84}$ LoPucki, above $\mathrm{n} 1$ at 1903.

${ }^{85}$ Ibid at 1905-6, including fn 80 .

${ }^{86}$ Bank of England, Finance for Small Firms: A Sixth Report, January 1999, p. 19 (footnotes omitted).
} 
was insolvent. However, twelve times as many businesses close without defaulting on any debts, as those that become insolvent. ${ }^{87}$ So Proposition $D$ is palpably false. We do not know how many tort debts go unpaid in liquidation, and the data relied on by the supporters of the Exploitation Hypothesis shows when there are large liabilities of this nature, little secured debt is issued and those liabilities are mostly met. So Proposition $B$ is either false, or more charitably, unproved. It must be said however that the likelihood of its being true is very remote indeed, for the reasons suggested above. We are left with Proposition $C$, that firms would issue secured debt to the liquidation value of their assets before liquidating. Even if true, this by itself would just beg the question, since why this should be so is precisely what the other -- false -- parts of the Hypothesis were trying to explain. Based on these predictions and data at least, few things are as demonstrably wrong in the debate about secured lending as the claim that it exists to externalise risk onto tort (or other 'involuntary') creditors.

Even apart from all this, there is an additional reason to question the proposition that the existence of the priority of secured claims leads to the exploitation of tort creditors in insolvency. This is because, in this jurisdiction, most tort creditors are unlikely to bear the insolvency risk of their debtors in the first place, regardless of whether the latter have borrowed secured. Here is why. While we face once again the problem that little empirical evidence is available on this point, it is very likely that most tort claims arise either from diseases contracted or injuries sustained at the workplace, or from road accidents. And in both situations, the claim would be covered by extensive compulsory insurance schemes. In the employment context, the Employers' Liability (Compulsory Insurance) Regulations 1998 now require most employers to have a minimum cover of $£ 5 \mathrm{~m}$ for all risks. This is complimented by the 'no-fault' Industrial Injuries Scheme. As for road accidents, the Road Traffic Act 1988 requires that users of motor vehicles secure unlimited cover in respect of death or personal injury. ${ }^{88}$ In either case, and should the insured party become insolvent, the Third Parties (Rights Against Insurers) Act 1930 effects a statutory transfer to the victim of the right to recover from the insurer. ${ }^{89}$ In addition, section 151 of the Road Traffic Act restricts the insurers' ability to refuse to pay the injured person on the basis that they would have been entitled to cancel or avoid the insurance contract as against the insured. Finally, even if the driver involved in a road accident is uninsured or untraced, the victim may have recourse against the Motor Insurers' Bureau to make good his loss. ${ }^{90}$ The cumulative effect of these provisions is to move the risk of the tort-feasor's insolvency from the victim to the insurer. This also means that any alleged "subsidy" that might have been created by subordinating tort claims to secured ones disappears: it is a fair bet the debtor's insurers would set premiums taking into account the level of risk associated with its business. ${ }^{91}$

If there is any concern that secured credit is purposely being used to defeat 'involuntary' liabilities on a large scale in this jurisdiction (as the Exploitation Hypothesis

\footnotetext{
${ }^{87}$ Ibid at 22 including fn 24, citing D. Storey, 'Firm size and performance', in Acs and Audretsch (eds.), Studies in Industrial Organization No. 11: The Economics of Small Firms (1990).

${ }^{88}$ Chris Parsons 'Employers' Liability Insurance - How secure is the system?' [1999] Industrial LJ 109, provides a helpful comparison and critique of the two regimes.

${ }^{89}$ A recent joint report from the Law Commissions of England and Scotland proposes greatly to streamline this legislation by, inter alia, allowing the injured party to proceed directly against the insurer before establishing the liability of the insured and without having to sue the latter, and by clarifying and expanding the circumstances in which the statutory transfer from the insured to the injured operates; see Third Parties - Rights Against Insurers (Cm 5217; SE/2001/134, July 2001). ${ }^{90}$ See eg Parsons, above n 88 at 125-6.

${ }^{91}$ To the extent that these premiums are based on an ex ante assessment of 'average' risk across a particular industry or sector of the market, the insurer itself may now be argued to be a 'non-adjusting' creditor seeking to be indemnified by the eventually insolvent debtor for what it pays out to the victim. To the extent that this is the case, the insurer's position falls to be addressed along with that of other 'non-adjusting' creditors, below.
} 
suggests), then it is surely imperative that empirical research be conducted to test whether that is the case. In particular, if significant amounts of tort debts are regularly going unpaid in corporate liquidations while secured creditors sweep up everything, that deserves to be a scandal and we should hear about it. However, such an argument (and a rather serious charge) would be difficult to sustain on the strength of a study based in a very different legal system; it could not be made at all on the basis of evidence that seems in fact to repudiate the argument. Nor can this evidence be employed to justify proposals to 'improve' the institution of secured credit, especially to 'protect' tort victims. ${ }^{92}$ It is suggested that unless hard facts and more persuasive arguments are forthcoming, the Exploitation Hypothesis should be retired from service. Tort claimants not being available for this purpose, critics of security must find someone else to save from secured creditors. ${ }^{93}$

\section{Exploitation and 'uninformed' creditors}

In view of the analysis above and given the present state of evidence and arguments, it is submitted the Exploitation Hypothesis is somewhat lacking in plausibility. That conclusion should carry over to this Section. Here, the exploitation is supposed to be of 'incompetent' ${ }^{94}$ creditors who systematically underestimate the risk of the debtor's business and who therefore charge less than they would if they could make a more accurate assessment. The argument is that the debtor can (as before) sell their insolvency share to secured creditors who, upon receiving security, do not then raise their rates (since their claims are not diluted by the addition of claims held by these 'incompetent' creditors), while enjoying under-priced loans from such creditors in the first place. The blame, it seems, lies with the deceptive nature of the institution of secured credit.

It should be clearly understood that the dispute here is about the existence of a class of creditor that is 'uninformed' about the need to deal with risk, and of the consequences of the existence of security. No one would deny that some creditors often do not have all the relevant information about a particular debtor. There is every reason to think there are informational asymmetries of this sort, both between creditor and debtor, and between different types of creditor. ${ }^{95}$ Rather, the controversy (insofar as it touches this point) concerns the argument that some creditors do not even realise the existence of such asymmetries, nor the consequences of their debtor's having borrowed on a secured basis, do not react appropriately in response, and are 'exploited' as a result.

\footnotetext{
${ }^{92}$ Finch herself does not seem to believe tort creditors are in need of special protection under English insolvency law; see Finch and Worthington, 'The pari passu principle and ranking restitutionary rights', in Rose (ed.), Restitution and Insolvency (2000), 1, 4. It is at least troublesome, then, attempting to reconcile this with the many arguments she makes that either the institution of secured credit, or the justifications provided in its support, are defective because they overlook the special position of tort creditors; see Finch, above n 11 at, eg, 655, 661, 662, 664, etc.

${ }^{93}$ The argument in this Section applies equally to Bebchuk-Fried's claim, above n 14 at 898-900, and again, above $\mathrm{n} 37$ at 1319-1320, that the priority of secured credit encourages firms to take insufficient precautions to minimise tortious harm for the reasons described by LoPucki. Their argument is fallacious (at least as applied to English law) because they pay no attention to the considerable costs of liquidation to shareholder-managers of firms which issue secured debt. To the extent to which their argument on this point is distinct from the Exploitation Hypothesis, it is examined further below.

${ }^{94}$ The term comes from Schwartz 'Security interests and bankruptcy priorities: A review of current theories' (1981) $10 \mathrm{~J}$ Legal Studies 1, 36. See also LoPucki, above n 1 at 1916.

${ }^{95}$ Indeed, some of the monitoring efficiencies said to arise from the existence of security build upon this proposition.
} 


\section{A. Uninformed In The Market}

It has to be said that the argument just summarised does not seem free of difficulties. First and importantly, it seems to ignore the fact that the required ability to deal with risk is not specific to the peculiarities of any one aspect of the legal system. So for example, a creditor would have to calculate the probability of its debtor's insolvency, or at least the average rate of default in its industry, even if there were no secured credit. It remains to be demonstrated that parties who can do this cannot then assimilate and react to the simple fact that general unsecured creditors do not often get anything in their debtor's (insolvent) liquidation. And contrary to this argument's basic premise, 'it is generally acknowledged that small firms today are more professionally managed -- by people with more business acumen -- and assisted by a wider network of support agencies. ${ }^{96}$ There is little reason to think this is any less true for firms that have to extend credit (probably almost all of them).

Further, LoPucki does not quite succeed in revealing who these 'uninformed' creditors are. The evidence he cites even for the existence of such creditors is, at its highest, anecdotal. ${ }^{97}$ LoPucki mentions a reported case as demonstrating the potential for exploitation of 'uninformed' creditors. However, as he himself notes, there was no 'exploitation' even there; the eventual decision of the Supreme Court of Illinois ensured that in fact, the 'uninformed' creditor prevailed! $!^{98}$ The LoPucki-Whitford study is also brandished again to show that 'in 4 of the 43 cases [] studied (9\%), the CEOs were indicted for fraud against creditors. In several others, the SEC brought administrative charges for such fraud. ${ }^{99}$ But of course this is all quite irrelevant as an argument against secured credit, the amount of secured debt being relatively minuscule for almost all the firms in the study. ${ }^{100}$ Again, if the argument is meant to show that secured credit exists (at least in part) to sell the share of 'uninformed' creditors to secured ones, the study itself consists of stunning counterexamples.

Given that the identification of 'uninformed' creditors is hazy at best and the evidence cited is inappropriate, this part of LoPucki's argument might well have been treated as no more than an irrelevance here. As it happens, though, Finch has seized on the basic insight that there might be a significant number of 'unsophisticated' creditors ready to be taken advantage of by security in this jurisdiction. She seems to make several arguments premised on the existence of parties who act as if they were 'uninformed', either because of personal or market reasons. ${ }^{101}$ Remember that they all aim to show how some players in the market systematically under-price their loans, thus allowing coalitions of debtors and security-holders to appropriate a part of their bankruptcy value.

First, Finch envisages a voluntary creditor who anticipates clearly that the granting of security by its debtor to another of its creditors would make its own position worse off. To compensate, it realises it should adjust the terms on which it does business in order to make

\footnotetext{
${ }^{96}$ BoE, above $n 86$ at 23 .

${ }^{97}$ A good example can be found at LoPucki, above $\mathrm{n} 1$ at 1916. But if the argument is to be won on the basis of anecdotes, then note the contradictory one provided by Knippenberg, above n 26 at $1971 \mathrm{fn} 19$.

98 Above n 1 at 1916-7, fn 115, citing Chicago Limousine Serv. v Hartigan Cadillac, 564 NE2d 797 (Ill 1990). LoPucki is still able to use this case since he is not satisfied with the grounds on which the 'uninformed' creditor was given victory; ibid. The reader is referred to the other US decisions he mentions.

${ }^{99}$ Ibid.

${ }^{100}$ See discussion of the LoPucki-Whitford study in the previous Section.

101 And they must be present in significant numbers, since an argument based on isolated exceptions could be used to support neither widespread criticism of the whole system, nor suggestions for dramatic reform.
} 
up for the expected loss of insolvency value. However, the industry in which it trades contains 'ill-informed and cavalier [operators who] may be willing to offer terms that undercut [our wiser but impotent protagonist] in the market. The [latter] will, accordingly, feel that it cannot adjust and, indeed, that resources spent on evaluating the need for adjustment... would be wasted.' The same calculation is made by many (or most) operators in the industry. This state of affairs is undesirable. ${ }^{102}$

The obvious reply must, with respect, be that operators who are 'cavalier' about accepting unjustified risks would soon go out of business, while the prudent operator who expends resources adjusting to risks would be rewarded with higher profits and commercial longevity. Finch herself notes a paragraph later that some 'trade creditors [would] have gone out of business through their failure to adjust -- perhaps in their early weeks and years.' She uses this as yet another argument against secured credit, stating that 'These lost enterprises involve costs to society. ${ }^{103}$ This is hard to understand. On her premises, in fact, such trade creditors should systematically include (by definition, since we are concerned with risk) a far higher proportion of those being 'cavalier' about it than those dealing with it prudently. Indeed, the more cavalier the operator or the more ill-informed it is about the consequences of its decisions, the more hasty should be its demise. ${ }^{104}$ The trend should be for the market to be purged of the cavalier and the ill-informed. The persistence in the market of such actors seems unlikely to account for the existence of security, nor does it seem likely to provide a significant source of exploitation.

Finch asserts that some 'ill-informed and ill-equipped' parties may be unable to adjust and unable to learn because they 'operate in dispersed, changing markets in which learning is difficult, the process of matching prices to risks may take a long time and may be delayed, distorted or prevented by changes of actors and the arrival in the market of numbers of unsophisticated operators who fail adequately to consider risks. ${ }^{105}$ This argument is, with great respect, not entirely satisfactory. What are these 'dispersed, changing markets in which learning is difficult', and in which industry do they exist? ${ }^{106}$ Why are parties compelled to operate in the whole of these dispersed markets? Parties who suffered from having to operate thus would soon specialise in one (or some) sector(s), thereby improving their ability to learn and adjust. Or some newcomers -- though aware that operators in this industry traditionally traded widely -- would be forced through financial constraints to start out on a small scale in one such sector (or in fewer ones than is customary), and would find (on Finch's assumptions) that they did better than competitors struggling in many different ones. Others would be likely to learn from their success and follow their example. Alternatively, suppose it is impossible (say for technological reasons) to specialise in some of these 'dispersed' markets rather than operating in them all. If so, the costs arising from the drawn out process of 'matching prices to risks' cannot be regarded as objectionable, since ex hypothesi these

\footnotetext{
${ }^{102}$ Finch, above n 11 at 644 (the operator in the example supplies roof tiles).

${ }^{103}$ Ibid.

${ }^{104}$ If operators resorting to a particular pattern of behaviour (say, any behaviour identified by Finch as demonstrating imprudence towards risk) did not suffer an increased probability of going out of business, then we would have serious reason to doubt the initial judgement that they were being 'cavalier' about risk in the first place.

${ }^{105}$ Ibid at 644-5.

${ }^{106}$ In LoPucki's version of this argument, each debtor is a separate market: 'The problem facing a trade creditor... is not what interest rate to charge, but to whom to extend credit and in what amounts. In doing so, the creditor is deciding which markets to enter' (LoPucki, above $n 1$ at 1956). But surely this is saying nothing more than that trade creditors have to be careful who they do business with. It would be hard to disagree, but this is true not just for trade or other unsecured creditors but everyone else in the commercial world (including secured creditors); all must decide carefully who to trade with. Since nothing distinguishes certain unsecured creditors in this respect from the rest of the world, no argument can be made that they represent a greater potential for exploitation than anyone else.
} 
costs cannot be avoided by any of the relevant players. It is submitted none of this constitutes an argument against the priority of secured claims.

\section{B. Uninformed Because 'Unsophisticated'}

Consider now the argument that, to this author at least, seems to have truly startling implications. The claim is that there might be 'a permanent subsidy to borrowers' because of the continuous flow into the market of 'ill-informed and ill-equipped parties' ${ }^{107}$ Parties who are merely 'ill-informed' because of market reasons would soon become informed; otherwise they would go out of business. So let us now focus on parties which are 'ill-equipped', presumably because of personal reasons, to learn from the markets etc. ${ }^{108}$ The assertion that these parties exist in the marketplace in significant numbers is meant to support proposals to 'improve' the system of secured credit to 'protect' them. ${ }^{109}$ Disregard for the moment that because of the purging effect of the market, such individuals are unlikely to be numerous at any given time, so that 'victimizing' them through the use of security is unlikely to be a profitable pursuit, and therefore unlikely to explain the ubiquity of secured credit. ${ }^{110}$

So the argument is that certain players enter into business some part of which requires them to extend credit. This in turn means they must understand (inter alia) how security operates in that industry, what are the laws governing its use, what the rates of default and of insolvency are in it, what commercial actors can expect if they do not have security and their debtor becomes insolvent, and if possible, what is the likelihood of their particular debtor defaulting or becoming insolvent. However, the players we are concerned with are 'ill-equipped' to meet (some of) these requirements. This means they underestimate the prices they should charge in order to be compensated, should their debtor become insolvent at some point after having issued secured credit. It also means they are ejected from the market more frequently than other players not as 'ill-equipped' as them. This leads to the conclusion that the institution of secured credit is both exploitative and inefficient.

This argument is troublesome. For one thing, the need to deal with risk is not related to the institution of secured credit, as already noted, and would inevitably exist even if no one ever lent secured. At least in a market economy, some business ventures would succeed and others fail, ${ }^{111}$ and those deciding to enter the market would have to make judgements about the likelihood of failure of their proposed business partners (their suppliers and buyers). Given the ever-present possibility of failure, they would be reckless indeed not to think of what would happen, should failure strike those they do business with. Such considerations would include questions about the resilience of their own venture in such circumstances. Further, if the economy is based on credit, the possibility of insolvency must be thrown into the mix. Business people must school themselves in the art of deciding what they should charge for their product, taking into account all these complexities of commercial life. The existence of secured credit simply is not implicated in the story so far. Once it is introduced, firms must learn to survive despite not being paid much on their outstanding loans to their counter-party (there would be some loss from a counter-party's insolvency, even if the latter had never borrowed on a secured basis). Parties 'ill-equipped' to deal with this rather trivial

\footnotetext{
${ }^{107}$ Ibid at 644-5 (emphasis added), citing LoPucki, above n 1 at 1956 (who refers, colourfully, to 'suckers').

${ }^{108}$ So we are concerned now with business people who, according to LoPucki, above n 1 at 1919, are at 'the lowest level of sophistication' or thereabouts.

${ }^{109}$ See eg LoPucki's proposals, above n 1 at 1957-63.

${ }^{110}$ To this effect, see the argument concerning tort creditors above; see also Schwartz, above n 94 at 346.

111 'Failure' in this context refers to a persistent inability to turn a profit, rather than to insolvency.
} 
additional complexity are unlikely to do much better even if the institution of security did not exist. $^{112}$

Suppose though that we accept that such 'ill-equipped' actors do occasionally enter the market, do then create a 'subsidy' for others by under-pricing their loans, and are ejected from the market quicker than others. Does this mean the institution of secured credit, perhaps by hastening their demise, is exploitative or inefficient, and ought therefore to be reformed? It should be noted first of all how difficult it is to assess the merits of such a suggestion. Suppose the level of protection accorded to 'ill-equipped' parties from the effects of secured credit were to be significantly increased. Some creditors would still inevitably fall below the threshold of that protection. What happens then? Since it is probably impossible to guarantee that no one would ever be 'taken advantage of' because of their inability to deal with commercial uncertainty and risk, or because of their ignorance of how banks operate, or because of their misinterpretation of the law of secured credit etc., all we could do would be to alter the threshold below which protection is denied. But for all we know, that threshold might lie roughly at the right level today. On this point, the most that can be said in favour of those proposing 'reform' on these grounds is that we cannot be certain, since they do not provide any information about how many such 'ill-equipped' creditors there might be today. This also means we cannot know how much 'protective' regulation should be added to cut down the number of those 'exploited' by way of secured credit by (say) one-half.

What is more, it does not seem to this author desirable for the law to ensure that members of society continue for as long as possible to do what ex hypothesi they are not very good at doing. Society has adopted the attitude that individuals are generally not to be prevented from entering the occupation of their choice. However, this same freedom necessitates that one must also face up to the consequences of that choice. So until society decides to abandon the position that the market should be allowed to encourage those not terribly good in their chosen profession to apply their talents elsewhere, surely no such argument would be persuasive in the debate about secured credit. Nothing justifies isolating 'unsophisticated' unsecured creditors from plumbers, actors, and soccer players of comparable abilities, so it is submitted that nothing requires them to be shielded from the consequences of their decisions any more than all others. Further and importantly, if the argument is that some business people cannot comprehend how security operates, can they understand and comply with tax and VAT, health and safety, consumer and environmental protection requirements, which are unlikely to be any less complicated? Those proposing 'reform' to the institution of secured credit on these grounds must surely bear the burden of demonstrating that all these issues can be satisfactorily addressed.

\footnotetext{
${ }^{112}$ In addition to the argument in the text, it is interesting to contrast the premises of this part of the Exploitation Hypothesis with the findings of one of the largest non-government surveys of its type ever conducted. It was undertaken by researchers at Strathclyde University on behalf of the Federation of Small Businesses, Barriers to Survival and Growth in UK Small Firms (October 2000). The 21,858 responses received from small businesses showed that, for factors 'internal' to the firm, 'satisfaction was greatest with regard to skill levels [of the businesses' own managers] in management, marketing and sales and the implementation of new technologies'; see pp 51-52 (including Table 49) and 60. In view of the arguments in this Section, it would surely be strange to assert such managers would consider themselves at a loss when required to digest the simple fact that, should one of their debtors become insolvent, they would receive little or nothing on the loans still outstanding, and that any assets in that debtor's estate would go primarily towards satisfying secured claims. This is especially true since their firm would often itself have borrowed on a secured basis and would be aware of the implications of this for its own creditors.
} 


\section{4. 'Non-adjusting' creditors, the Inefficiency Hypothesis, and the rate reduction assumption}

Bebchuk and Fried have given the most systematic statement of what here will be called the Inefficiency Hypothesis. ${ }^{113}$ They argue that "under the rule of full priority, the creation of a security interest diverts value from creditors that do not "adjust" the size of their claims to take into account the effect of the loan transaction that creates the security interest' ${ }^{114}$ Security allows the debtor to transfer to secured creditors some of the insolvency value of such 'non-adjusters'. In return, the secured creditor charges them a lower rate of interest, reflecting the fact that its claim would not now have to rank pari passu with those of nonadjusting creditors. A 'non-adjusting' creditor, then, is one who 'cannot or does not adjust the terms of its loan to reflect the effect on its loan of all the arrangements the borrower enters into with other creditors, including the creation of security interests which, under full priority, completely subordinate the nonadjusting creditor's claim in bankruptcy., 115

Bebchuk and Fried are more at ease than LoPucki accepting that security might be beneficial and efficient as well as merely redistributive (from non-adjusting creditors to debtor and secured creditor) and inefficient. They explain that since the security interest encumbers the collateral and affords the secured creditor both a superior remedy and priority to the proceeds of its realisation, it reduces the borrower's ability to overinvest by selling those assets and embarking on an inefficient project. It discourages asset dilution by way of transfer of those assets to the debtor's shareholders. It reduces the costs to the secured debtor of dealing with a default. Security also discourages inefficient behaviour on part of the debtor by increasing the expected costs of non-compliance with value-increasing covenants in the loan contract. ${ }^{116}$

Here is how the inefficiencies are supposed to arise. Bebchuk and Fried accept that to the extent that security increases the wealth of all the parties, it is of course desirable. But security interests will be granted beyond this point not because of their social benefit, but simply because they allow the debtor to reduce its own financing costs by selling the insolvency share of non-adjusters. On the margins, therefore, the role of security is merely redistributive. And second, security interests would sometimes be used precisely for redistributive purposes when debtor misbehaviour might more effectively have been controlled by use of non-security covenants. ${ }^{117}$

This, then, is the Inefficiency Hypothesis, and we must decide what to make of it. It is submitted the Hypothesis is seriously undermined - at least as it applies to this jurisdiction by empirical evidence now available. However, the same evidence also calls into question one of the most deeply embedded and seemingly obvious intuitions underlying the debate about security. This is what we must begin by unearthing. It is important to notice the structure of the argument above. According to Bebchuk and Fried, the existence of secured credit does allow the secured creditor to control debtor misbehaviour. This benefits all of those with claims against the latter, and therefore maximises social value. The secured creditor-to-be anticipates the lower costs to it of administering this loan in the way described

\footnotetext{
${ }^{113}$ Similar concerns have been expressed in the English context by Finch, above n 11; this, together with the Exploitation Hypothesis discussed above, constitutes what she describes as 'the core objection to the provision of security'; see at 644.

${ }^{114}$ Bebchuk and Fried, above n 14 at 864.

${ }^{115}$ Bebchuk and Fried, above n 37 at 1295-6; see also Bebchuk and Fried, above n 14 at 864-5 and 88291. The categories of non-adjusters are described at 882-91.

${ }^{116}$ Ibid at 872-6.

117 These are the most important of the alleged inefficiencies described in Bebchuk and Fried, above $\mathrm{n}$ 14 at 895-903.
} 
above, and of an increase in its share of bankruptcy value, and so lowers the interest it charges. The debtor for its part offers security to enjoy the benefits of this lower interest rate. As the argument is presented, the problem arises only after all the gains from the secured creditor's ability to control debtor misbehaviour have accrued. Beyond this point, the secured creditor will lend cheaper on a secured rather than unsecured basis only because the priority associated with secured status allows it to obtain a greater part of the debtor's estate, should the latter become insolvent. And the debtor still has an incentive to offer security because of the attraction of cheaper loans from the secured creditor. Now security is doing nothing but transferring bankruptcy value from one set of creditors to another. The losers in this process can do nothing about it since, ex hypothesi, they are unable to adjust the terms on which they lend. ${ }^{118}$

Now, the linchpin of this argument, the assumption that does all the work here, is the obvious one that secured credit is cheaper than unsecured credit. Call this the 'rate reduction assumption'. The assumption seems reasonable: after all, having priority does (by definition) improve a creditor's position in its debtor's insolvency compared to what it would otherwise be. So this difference must obviously be reflected in the price to be charged for debt. Of course if there were no difference in rates between secured and unsecured debt, then this argument simply would not work. It is important to understand why. If the assumption holds, secured creditors-to-be are indifferent between being asked to lend unsecured and charging a high interest rate on the one hand, and taking security and reducing the price of their loan on the other. It is the debtor that has an incentive to offer security, precisely because it can pocket the difference in interest rates. If there were no difference between borrowing secured and borrowing unsecured, there would from the debtor's perspective be a strong disincentive to offer security. We should remember that on Bebchuk and Fried's premises, security has two broad roles. It may facilitate a transfer of bankruptcy value from non-adjusting to secured creditors, but this transfer is consummated only once the debtor becomes insolvent. While it is still solvent, however, security allows the secured creditor to restrict the debtor's freedom of action, preventing it from engaging in over-investment, asset dilution, and because of the 'hostage' role of security, extracting from it scrupulous compliance with debt covenants. The debtor's shareholder-managers suffer from the existence of security, on Bebchuk-Fried's view. So they must be compensated handsomely through a reduction in price of the nowsecured loan, if the debtor is to offer security at all. ${ }^{119}$

The rate reduction assumption is quite crucial to these major attacks on security, then. ${ }^{120}$ And so strongly accepted is it that the defence of the priority of secured credit in this paper so far has also proceeded as if it were true. ${ }^{121}$ Yet it is now contended that there is reason to think the way this assumption operates in the attacks on security is quite fallacious

\footnotetext{
${ }^{118}$ This strategy of argument is obvious in, eg ibid at 891-5 and 896-7.

${ }^{119}$ Very importantly, this strategy of arguing against the priority of secured lending is by no means unique to Bebchuk and Fried. Both limbs of the Exploitation Hypothesis, discussed above, are also premised on the rate reduction assumption. This is apparent, eg, from LoPucki's numerical example, reproduced in Section 2A. See also LoPucki, above n 1 at 1897-9 and 1916-20, and Finch, above n 11 at 645-6.

${ }^{120}$ In Finch's case, it can be found explicitly in, eg ibid at 638: 'If both parties are rational and informed..., even the most powerful debtor is likely to be presented with a choice by the creditor -between a certain interest rate in combination with security and a higher interest rate without security'. Implicitly, of course, this assumption is present whenever she relies on any of LoPucki's or Bebchuk and Fried's arguments, or herself makes arguments with a similar structure.

${ }^{121}$ So that defence would stand even if the following arguments could be rebutted. The rate reduction assumption is also accepted (though in the US context, which might make a difference) by two of the most insightful challenges to the Inefficiency Hypothesis, those by A. Schwartz 'Priority contracts and priority in bankruptcy’ (1997) 82 Cornell LR 1396, Section IV, and S. Schwarcz, above n 10.
} 
(at least in the English context). The evidencefor this is discussed below. It would be helpful first to set the theoretical context of this relationship between risk, interest rates and security.

Let us start by disentangling two distinct factors that might be at play in determining whether the rate reduction assumption is valid. The first one, which the literature refers to as financial agency costs, has already been mentioned. The debtor's management has an incentive to engage in behaviour harmful to its creditors. They might 'overinvest' by putting the borrowed capital in projects with a negative present value, or dilute the existing lenders' claims by borrowing more, or simply by distributing corporate assets to shareholders in the form of excessive dividend payments. Since all these activities increase the prior lenders' risk, those capable of adjusting their rates would have an incentive to demand a higher interest rate at the time the loan is made. Now to the extent that security mitigates this risk (by discouraging misbehaviour), it serves as a substitute for a higher interest rate. Very simply put, a secured loan is for this reason likely to be cheaper than an unsecured one, all other things being equal. But as already pointed out above, to the extent that this factor explains the relative cheapness of secured debt, it is accepted by critics like Bebchuk-Fried to be beneficial to all of the firm's creditors, unsecured as well as secured (since financial agency costs hurt them all).

But the second of the two factors just mentioned might ensures that the relationship between security and interest rates is not always inverse. From the lender's perspective, and focussing for a moment only on unsecured loans, raising interest rates beyond a certain point might well be self-defeating. This is because potential borrowers who offer to pay more ex ante, may not end up paying more ex post. Those offering to borrow at higher interest rates might be willing to do so only because they intend to undertake riskier projects, or are overestimating the success or profitability of their projects, or are simply dishonest. It follows that as the interest rates charged by a lender creep up, the average quality of its borrower would tend to decline. This adverse selection effect also means that as interest rates increase, less risky borrowers would drop out of the market, finding credit to be prohibitively expensive (remember that their lower-risk projects also yield lower returns). What is more, rates increased in order to compensate the borrower against the risk of debtor misbehaviour, might in fact generate additional motivation costs, as debtors are pushed into taking excessive risks to finance the higher costs of borrowing. Instead of compensating the lender for its portfolio risk, then, high interest rates might increase that risk. One way of avoiding this 'moral hazard' problem would be for the lender to 'ration' credit instead of raising rates. Keeping the rates lower would attract better-quality borrowers back into the market. It would also ensure, however, that some good potential borrowers who nevertheless have an ex ante risk profile necessitating a somewhat higher rate do not obtain credit. ${ }^{122}$

Introducing security back into the picture, we can now see that it might sometimes substitute, not for higher interest rates, but for refusing credit altogether. Some loans might be made because the lender's ex ante risk is mitigated by the priority it would now enjoy in any subsequent insolvency, when without that priority, an 'adequate' interest rate would be beyond the level where the adverse selection and moral hazard problems become acute. Importantly for our purposes, it should be noted that in this situation, the rate reduction assumption turns out to be the rate reduction fallacy. Here, the choice would not be between borrowing at a high rate without offering security, and obtaining a lower rate by offering it. It

\footnotetext{
${ }^{122}$ This discussion draws on the work of Joseph Stiglitz and Andrew Weiss; see eg 'Credit rationing in markets with imperfect information' (1981) 71 American Economic Review 912, 'Credit rationing and collateral', in Edwards, Franks, Mayer and Schaefer (eds.), Recent Developments in Corporate Finance (New York, CUP, 1986), and 'Banks as social accountants and screening devices for the allocation of credit' (National Bureau of Economic Research Working Paper No. 2710, Cambridge, MA, September 1988).
} 
would instead be that between borrowing (at a relatively high rate) by offering security, and not borrowing at all.

To the extent that this analysis holds, we have a way of testing the anti-security Hypotheses. Both predict that for troubled firms which might eventually become insolvent, there should be a difference in the price of secured and unsecured loans made by banks (i.e. creditors which lend both with and without security), secured credit being cheaper. On the other hand, if such a relationship is lacking, then we have reason to doubt the validity of the anti-security attacks, at least as they stand. We would then have to decide whether the ability of security to avoid the adverse selection and moral hazard problems itself creates costs for unsecured creditors.

Now for the relevant evidence, which comes from a recent study conducted by Julian Franks and Oren Sussman (hereafter, 'Franks-Sussman') on behalf of the Working Group on Company Rescue and Business Reconstruction Mechanisms. ${ }^{123}$ Franks-Sussman persuaded three large UK clearing banks to grant them access to private records on 542 companies, all of which had entered the central 'rescue units' of these banks during a certain sampling period. The stated purpose of these units is to 'intervene early in the cycle of a company's decline and provide a greater opportunity for rescue and recovery, without necessarily resorting to formal procedures' ${ }^{124}$ Firms in the unit are kept under close supervision, and might either recover and be sent back to the bank branch, or close their account and take their business elsewhere, or come to be regarded as beyond (informal) rescue and consigned to another of the bank's units (the 'debt recovery unit') and then perhaps to a formal insolvency procedure. ${ }^{125}$

An important test conducted by Franks-Sussman on the data obtained from one of the banks was aimed at discovering the relationship between interest rate spreads and the characteristics of firms as they entered the bank's rescue unit. ${ }^{26}$ Two of their findings are particularly relevant here. First, the relationship between the ratio of security value to bank debt on the one hand and the interest charged on the loan on the other, while being an inverse one, was the second least significant (approximately) of all those tested. In other words, how much of the bank's debt was secured was only marginally related to the interest charged on the loan, if it was related at all. ${ }^{127}$ Changes in the interest rate were to be explained

\footnotetext{
${ }^{123}$ Franks and Sussman, The Cycle of Corporate Distress, Rescue and Dissolution: A Study of Small and Medium Size UK Companies, Institute of Finance and Accounting (London Business School) Working Paper 306-2000, 2000 (hereafter, Cycle); the Working Group was set up jointly by the Department of Trade and Industry and the Treasury. See also the revised version of the paper, 'Resolving financial distress by way of a contract: An empirical study of small UK companies' (22 October, 2000), available at URL:<www.ifk-cfs.de/papers/franks.pdf> (hereafter, 'Resolving'). ${ }^{124}$ Cycle at 4, and 'Resolving' at 12.

${ }^{126}$ There is some reason to be cautious about how far this data can sustain generalisations, given the noticeable 'diversity in lending strategies within English banking' also discovered by the authors; see 'Resolving' at 28. The following analysis should therefore be read as based on the best and most current data now available, but (needless to say) always subject to revision as the results of any more extensive investigations become known. Of course this point cuts both ways, so that the generality of the predictions of the anti-security Hypotheses must also be treated with at least as much caution.

${ }^{127}$ The emphasised part of this statement is crucial. The relevant t-statistics in Cycle at 22, Table 11, indicate that there is no statistically significant reason to reject the hypothesis that the regression coefficients are zero. Put very simply, we cannot say, in a statistically meaningful way, that offering security leads to a reduction (or indeed an increase) in interest rates. Compare the findings of the UK Competition Commission, which was told by the main 'clearing groups' of UK banks that one of the eight factors affecting the level of margin was security: 'Secured loans generally have lower margins than unsecured ones' (emphasis added); see The Supply of Banking Services by Clearing Banks to
} 
overwhelmingly by factors other than the proportion of bank debt secured. And second, there was a 'highly significant' direct relationship (perhaps the second strongest of all the factors considered) between whether the bank had been given personal guarantees for some part of its loan, and the interest it charged on it. ${ }^{128}$ The greater the likelihood that a guarantee had been given, the higher the interest charged.

This has dramatic implications for the Inefficiency - and equally the Exploitation Hypotheses. For this data at least, it simply is not the case that a debtor can mechanically obtain a reduction in its interest bill by offering security. This should be read together with Franks-Sussman's finding that bank debt was 'almost universally secured' through a combination of fixed and floating charges. ${ }^{129}$ It does not, then, seem to be a matter of choice for the debtor to bargain with its main bank, offering security in return for a lower interest rate. ${ }^{130}$ Security will be extracted as a matter of course from companies likely to end up in the bank's rescue unit (and therefore those most relevant to the two Hypotheses), ${ }^{131}$ and it may not lead to any noticeable reduction in interest charges. For such companies, and consistent with the analysis above, the difference between offering security and not offering it does not appear to be that between borrowing at lower or higher rates, but more likely that between borrowing and not being able to borrow at all. ${ }^{132}$ As explained above, both the Inefficiency and the Exploitation Hypotheses are heavily dependent on the contrary assumption to explain why security is asked for and offered. Both must therefore be considered weakened.

That is not all. Suppose we take the interest charged on the bank loan to be related to the bank's assessment of the borrower's riskiness. ${ }^{133}$ The discussion above indicates taking security over the latter's assets is by no means the most discriminating way in which the bank responds to this risk (since security is taken anyway from this type of firm, and since the extent to which it covers the loan is not strongly associated with the interest rate). In fact, a more focused method of dealing with risk seems to be to extract a personal guarantee from the firm's shareholder-managers. Only this explains the 'highly significant' relationship between the incidence of such guarantees and the rates of interest. The riskier a firm is perceived to be, the higher the interest it is charged (of course subject to the limits set by the adverse selection and moral hazard problems), and the more likely its directors are to be

SME's (HMSO, March 2002), paras. 4.151-4.160. Evidence from both sources is consistent with the combined effect of the agency cost reduction effect (often leading to lower rates, and also explaining the negative sign for this variable in the Franks-Sussman study) and the adverse selection/moral hazard avoidance effect (meaning rates are not always lower, especially for firms in distress).

${ }^{128}$ Cycle at 21-2, including Table 11. Very importantly, 'many of these guarantees will involve directors' personal property'; see 'Resolving' at 15.

129 'Resolving' at 14, and Cycle at 9, Table 4.

${ }^{130}$ Milman and Mond, above n 11 at 37, have rightly noted that 'banks tend to offer little choice over matters of security.'

${ }^{131}$ In other words, security (including directors' guarantees, discussed below) is demanded on the basis of a 'pre-loan' appreciation of the loan's riskiness; for the suggestion that this is the very time at which to ask questions about why security is taken, see Mann, above n 29 at 637 . For symmetry, it can be added that firms (of the appropriate size) are consigned to the banks' 'rescue units' in response to what happens during the currency of the loan. This is of course a rough distinction, so that, eg, security might be taken half way through the duration of the loan because of circumstances which only then become apparent to the lender.

${ }^{132}$ This has implications quite crucial to the debate about secured credit; see Section 5, below.

${ }^{133}$ This is a very plausible assumption; see eg 'Resolving' at 23. Other factors will of course be relevant here as well, perhaps including the competitiveness of a particular market for bank loans; for mixed evidence in support of the relevance of this factor, see Cruikshank, Competition in UK Banking (2000) at 153-4, including fnn 7 and 8. 
required to provide personal guarantees. ${ }^{134}$ The finding that the incidence of directors' guarantees seems remarkably more discriminating than that of security over the firm's assets ${ }^{135}$ also strongly supports the view that, amongst the firms likely to end up in its rescue unit, this is the method the bank uses to separate the riskier from the less risky borrower.

We should think again about the two Hypotheses we are testing. Both assert that security is offered because the debtor (and here this must mean its shareholder-managers) wishes to sell off the insolvency share of involuntary, uninformed, or non-adjusting creditors (more accurately put, only when this happens do the criticisms implied by the two Hypotheses kick in). So (a) the reward they receive in all cases is the reduction in interest rates, and, (b) their insolvency costs are unaffected. We can see however that both limbs of this type of argument are wrong. As the riskiness of the firm's activities increases, (a) the interest charged to the firm may go up, and (b) the shareholder-managers' private (insolvency-linked) expected costs also increase. ${ }^{136}$ This evidence shows that regardless of the existence of security, operating riskily and aiming at a strategic liquidation becomes increasingly unattractive, and any incentive to create tortious harm (in the expectation that it could later painlessly be defeated through insolvency) diminishes even further. The Exploitation Hypothesis is therefore deprived of any vestigial plausibility. And there remain neither incentive nor scope for debtors to sell the insolvency share of non-adjusting creditors to a secured creditor in order to pocket the interest payment savings (there being none). So the Inefficiency Hypothesis too starts to crumble.

There is yet another finding of the Franks-Sussman study that - to the extent that it can be generalised - should be regarded as fairly decisive against the type of attack on security now being discussed. This concerns the relationship between interest rates and the ratio of bank debt to total debt. Let us think about what we should expect this to be, if the lines of argument we have been considering (derived from the two Hypotheses) led to truth. The way the rate reduction assumption is made implies that the borrower has two options. It can either operate sensibly, not increase the risk of default faced by its creditors, take reasonable precautions to prevent tortious harm, and enjoy a relatively low interest rate on the unsecured loan from its main bank. Alternatively, it can engage in risky activities which increase the variance of its returns and thus its shareholder value, but also simultaneously its chances of facing an insolvent liquidation. It can save money by not taking sufficient precautions against potential tort liability. But it can then issue security to its bank and thus continue to enjoy the same (or in any case, not significantly higher) rates on the loans made to it by the latter. The bank's pricing decision is very simple. In the first scenario, the bank anticipates a low probability of default on its loan, and a small pool of other claims with equal priority with its own, and thus charges a low interest rate. In the second, it anticipates a higher probability of default, a large number of other claims, but still the same expected recovery on its loan because of the priority it now has. So it charges more or less the same

\footnotetext{
${ }^{134}$ So here (as, with great respect, on so many other occasions), Goode seems to have been right after all when he observed (well before the Franks-Sussman study), in Principle of Corporate Insolvency Law (2nd edn, 1997) at 41, that 'It is assumed as an article of faith that a creditor taking security will charge a lower rate of interest than one who lends on an unsecured basis... But this is simply not how lending works. Banks charge what they consider the market will bear. A bank does not quote a lower rate of interest because it is secured; it takes security because of a perceived risk of non-payment and may charge a higher rate because of the risk. Similarly, the mere fact that a loan is unsecured does not necessarily mean that the bank will charge a higher rate' (emphasis in the original, footnote omitted). We now know of course that security is taken as the risk on the loan rises (and higher interest rates would cause adverse selection and moral hazard). For especially risky firms, the interest rate very clearly goes up, and guarantees are demanded from the firm's directors.

${ }^{135}$ Contrast the respective figures in Cycle at 9 Table 4.

${ }^{136}$ Since their personal assets are threatened if their firm becomes insolvent.
} 
low interest rate. The number of other claimants simply does not matter to it, as long as it has priority over all of their claims. This is how the rate reduction assumption operates in the two Hypotheses. In view of this, and given the near-universality of security in the FranksSussman data set, we should expect no significant relationship between interest rates and the proportion of bank to total debt.

A different prediction emerges from the two Hypotheses for debtors which were more obviously and seriously in trouble before eventually being liquidated insolvent. Here, the secured creditor (in practice, the bank) would have a higher expected rate of recovery in the debtor's insolvency if it had available to it a 'cushion' of value provided by other creditors. This is the bankruptcy value supposedly sold to it through the use of priority by the debtor. The latter is rewarded with lower interest rates. The bigger the cushion, the greater the protection accorded to the secured creditor. It follows that the bigger the cushion, the lower the interest rates charged by it. ${ }^{137}$ Now the size of this cushion is inversely represented by the ratio of bank to total debt. The smaller the proportion of total debt that is owed to the bank, the greater is the protection available to it. This is because the debt owed to the priority-holding bank is more likely to be repaid (and repaid in full), the greater the proportion of the debtor's estate derived from value provided by the other, subordinate, creditors. And on the views being explored, it is precisely because the secured creditor expects to be able to appropriate (some of) this value that it would reduce its interest charges. On the strength of the two Hypotheses, then, and to the extent that this contingency could be reflected in interest rates, we should expect a direct relationship here: the smaller the ratio of bank to total debt, the lower the interest charged by the bank. And since this mechanism is supposed to explain much (Exploitation) or at least the objectionable bit (Inefficiency) of the ubiquity of security, this relationship should be fairly significant. So if the Hypotheses have any validity, the relationship between the ratio of bank to total debt and interest rates should either be direct and significant (as explained in this paragraph), or simply insignificant (as the previous paragraph explains).

Franks-Sussman's findings for this variable were indeed 'highly significant' (one of the strongest of all the relationships tested). They were also exactly the reverse of what the anti-security Hypotheses would have us expect! In other words, the greater the proportion of total debt that was owed to the bank, and therefore the smaller the cushion of value provided by other creditors (and thus available for appropriation to the bank), the lower was the interest rate charged on its loan by the bank. ${ }^{138}$ To the extent that the implications of these findings can be generalised, then, secured creditors very clearly do not display predatory intentions towards value contributed by other creditors, at least in the pricing of their loans. Nor, it therefore follows, do they create an incentive for the debtor to 'sweep in' significant amounts of this value in order to sell it to the secured creditor in return for lower interest rates. In fact, as we have just seen, secured creditors seem positively to discourage debtors from borrowing too much from other creditors by unambiguously charging them higher interest rates, the greater the proportional value derived from other creditors. This surely leaves little room for doubt. It is submitted this - in addition to all the other evidence discussed in this paper - proves that arguments meant to explain the prevalence of secured credit, but based on debtor-secured creditor coalitions extracting 'subsidies' from an assortment of involuntary, uninformed, 'ill-equipped', and non-adjusting creditors, all just do

\footnotetext{
${ }^{137}$ At least until the point where the secured creditor's risk diminishes to a level where the cost to it of offering lower interest rates outweighs the benefits to it of further risk reductions.

${ }^{138}$ Cycle at 21-2, including Table 11.
} 
not hold water. ${ }^{139}$ Therefore, very simply, they cannot be used to base suggestions for 'improvements' to the institution of secured credit. ${ }^{140}$

\section{Informal 'rescues', trade creditors and the bank's share}

In the arguments in the previous Section, considerable reliance has been placed on certain of the findings of the recent Franks-Sussman study. As argued above, the study goes a long way to disproving crucial assumptions underlying the most important existing attacks on the priority of secured credit, as well as some of the predictions that can be derived from them. But the same study also highlights an aspect of the way banks operate in this jurisdiction that might be thought to provide new ammunition to critics of security. That is what this Section considers.

As already noted, Franks-Sussman discovered an extensive and elaborate process of 'intensive care' operated by all three of the banks they studied for firms that were taken to be heading for trouble. Firms were consigned to these 'central rescue units' based on the bank's own criteria, and subject to considerable discretion in credit officers at individual branches. They remained there for an average of seven and a half months. ${ }^{141}$ There could be one of three outcomes of this process. The firm might be 'turned around' (rescued) and returned to its bank branch. Or it could be sent to a 'debt recovery unit' for the initiation of a formal insolvency procedure. Or finally, it could repay all its loans to the bank, terminate the banking relationship, and presumably re-bank elsewhere.

The discovery which interests us now is that, while in the 'rescue unit' and subject to close supervision by specialised bank officials, the troubled companies paid off, on average, between $30-40 \%$ of their bank debt. At the same time, the debt owed to trade creditors increased by between 10-30\%. ${ }^{142}$ This was the case overall, both for firms which were eventually rescued and 'returned to branch', and those which were sent to the 'debt recovery unit' for formal insolvency proceedings. The picture was quite similar if the latter were considered in isolation. For one of the banks, Franks-Sussman found that 'the bank never extends further loans to a company that is placed eventually in bankruptcy... although the trade creditors do so quite often. ${ }^{143}$ On average for this bank, bank credit shrank by almost $14 \%$ and trade credit grew by over $11 \%$ while the company was in the 'rescue unit'. Given that in the insolvency proceedings that followed for these companies, the bank would have priority over trade creditors, this amounted to 'almost a direct transfer from the trade creditors to the bank.' This despite the fact that, as the authors noted, 'trade creditors are

\footnotetext{
${ }^{139}$ Several such arguments are made in the English context by, eg, Finch, above n 11 at 644-6.

${ }^{140}$ Even in the US context, where the analysis so far in this Section may or may not apply, Bebchuk and Fried's proposals to restrict the priority of secured credit, based on the arguments discussed here, have not been entirely persuasive. ' $[\mathrm{H}]$ aving received hardly any support among members of the task force [on bankruptcy issues, comprised largely of bankruptcy specialists, appointed to assist the Drafting Committee to Revised Uniform Commercial Code Article 9] and no support whatsoever from anyone who ever attended a meeting of the Drafting Committee, these proposals were rejected. The proposals were advocated also before the Council of the [American Law Institute] and at a [National Conference of Commissioners on Uniform State Laws] Annual Meeting, where they met with almost unanimous disapproval'; Harris and Mooney 'How successful was the revision of UCC Article 9? Reflections of the Reporters' (1999) 74 Chicago-Kent LR 1357 at 1359 including fn 6. Decision-makers and scholars in this jurisdiction surely should not rush to embrace arguments based on a very different legal system, when those arguments have received such a frosty reception in the very jurisdiction where they originated.

141 'Resolving' at 11.

142 'Resolving' at 20-1, and Table 4.

143 'Resolving' at 21 and Table 5.
} 
typically small, undiversified, and highly exposed to the risk of default. Unlike the bank, they have no comparative advantage in bearing these risks. ${ }^{144}$

It would not be surprising if some critics of security seized upon these results as proof, at last, for one or other of the anti-security Hypotheses. Surely security is being used, very simply, to siphon away value from trade creditors? The temptation to use these figures to paint -- with a broad brush -- a picture of exploitation on part of secured creditors might well be strong. It is submitted this temptation is best resisted if the aim is instead to acquire an accurate picture of these figures. The first point to note is the obvious one that the movement of funds from trade creditors to the company in the rescue unit, and from it to the bank, as depicted in the previous paragraph, is based on averages across the client firms of this particular bank. This is significant here because these averages hide what in fact are the 'great variations in the record of debt repayments' to trade creditors and the bank during the time the firm was under bank supervision. This is obvious, for example, from a comparison of firms arranged with reference to the amount of debt outstanding at the time of entry into the 'rescue unit'. For companies in the bottom quartile, 58.7\% of bank debt was indeed repaid on average. However, this figure decreases to $18.2 \%$ for those in the next quartile up. For companies in the top quartile, bank debt actually increased by $29.1 \%$ while the firms were under close scrutiny by bank officials. ${ }^{145}$ So the first conclusion to be drawn is that security is not accurately regarded as merely a mechanism for appropriating value provided to the troubled firm by trade creditors. In fact, as noted, there are very significant differences in bank strategy in dealing with firms of different sizes. ${ }^{146}$ For larger firms, the (securityholding) bank actually injects additional value into the firm, which amounts on average to a third of what it was originally owed.

Next, we should note that there is a fairly straight-forward correlation between the repayment of the troubled firm's bank debt, and the sale of assets by the firm itself. Almost half the firms in the 'rescue unit' reported 'significant asset sales in the rescue process'. In interpreting this data, it is important to keep in mind both the priority-based nature of security, and the fact that the 'absolute priority rule' (which requires senior creditors to be paid off before junior claimants get anything) is quite firmly entrenched in this jurisdiction. Given these factors, the finding that the firms which sold off assets usually applied most of the proceeds to pay off their bank debt should come as no surprise. ${ }^{147}$ If any assets become available during the rescue process, the bank as senior claimant obviously has the first right to them. The important thing to note here is that this is merely a manifestation of the nature of security. It is not, by itself, evidence that security is exploitative. Critics of the priority of secured lending have to say something more than that secured creditors have priority! The data so far mentioned supports only the latter proposition. It also shows once again that the relationship between value provided by trade creditors and that withdrawn by the security holder is not as clear-cut as the average figures mentioned above misleadingly suggest. Much of the repayment of bank debt (though certainly not all) can be attributed to the sale of assets, rather than to the appropriation of value injected by trade creditors.

The obvious question then is: why the apparent beneficence towards larger distressed companies, and in turn towards their trade creditors, as noted above? Further analysis carried out by Franks-Sussman provides an interesting insight. A 'striking explanation' for the differences in repayment of bank debt is 'the incidence of managerial turnover'. The data shows that firms which owed the bank more (and were thus presumably larger) were more likely to replace an important member of the managerial team. For such firms, the bank

\footnotetext{
${ }^{144}$ Cycle at 19 Table 10 at 18 and 16.

${ }^{145}$ Cycle at 10-1, including Table 6 Panel B.

${ }^{146}$ Franks-Sussman use the amount of total debt outstanding as a proxy for firm size.

${ }^{147}$ Cycle at 10-1, including Table 6 Panel B.
} 
contracted its debt by a mere $1.2 \%$. Smaller firms changed their management much more rarely, and the bank contracted its debt to them to a far greater degree, at $28.3 \%$. ${ }^{148}$ This is consistent with the point made in Section 2 of this paper, that managers of smaller firms, who also own most of the equity in it, would have huge undiversified pecuniary, and undiversifiable non-pecuniary, investments in the firm. It simply does not make sense for them to let go of control of the firm, since the costs to them of doing so are great. They prefer to remain at the helm even when that increases the probability their firm would be unable to survive a particular crisis. This should be read together with the finding that the higher the probability that a manager would be replaced, very significantly greater is the chance that the firm would be successfully rescued, of course to the benefit of all including trade creditors. ${ }^{149}$

All this shows that any conclusion that the bank simply uses its security to appropriate value from trade creditors would be crude and inaccurate. In reality, the position seems to be that the bank employs the leverage provided to it by security 'to encourage (or force) distressed firms to undergo restructuring, that includes downsizing and managerial replacement. [Both these factors appear] to be significantly [and inversely] related to the size of debt repayments demanded by bank'. They are also significantly (and positively) related to the probability of a successful rescue. ${ }^{150}$ All the concerned parties, including trade creditors, are much better off if their debtor recovers than if it is liquidated. ${ }^{151}$ An overwhelming proportion of attempted rescues (around 75\%) succeed without formal insolvency proceedings. ${ }^{152}$ All this happens in the bank's 'rescue unit' under close supervision by its officials, and as noted, is made possible by the leverage provided to the bank through its priority position. The bank's officials of course monitor the firm in the unit and gather data about it, then use it to encourage the firm (in general, successfully) towards a turn-around. They use this same data, it seems, to ensure the debt owed to the bank is paid off first when the firm is not likely to recover, even while the less-informed trade creditors continue to pump value into the sinking firm.

It appears, then, that one of the costs of the elaborate monitoring done by the banks of the distressed firm is the chance that if the firm does not recover, the bank would be paid even at the expense of the firm's trade creditors. But it should be emphasised this by itself is not an argument against either the efficiency or indeed the fairness of the priority of security, since no one, to this author's knowledge, has suggested that outside monitoring of distressed firms does not have costs. The point is that this same monitoring also seems to bring the great benefit to all, including trade creditors, of a very significant chance of successful rescue of the debtor. It follows that to make an argument against security, one would have to conclude either (or both) of two things. First, one would have to show that the removal or reduction of the priority of secured lending would not impede the secured creditor's ability to monitor and influence the debtor. Alternatively, it would have to be demonstrated that the benefit of an increased chance of successful rescue associated with this monitoring is outweighed nevertheless by whatever harm results from it in case of that minority of firms for which this monitoring does not lead to rescue. ${ }^{153}$ Till such an argument is made (and made successfully),

${ }^{148}$ Cycle at 11 , including Table 7.

${ }^{149}$ Cycle at 23 including Table 23.

${ }^{150}$ Cycle at 24 and 23.

${ }^{151}$ For arguments in support, see below, and also Schwarcz, above n 10; for data, see Cycle, eg at 18 .

${ }^{152}$ Cycle at 2 and 24; 'Resolving' at 4 and 30, etc. This, as well as the incidence of 'going concern' sales in receivership, compares very favourably with more 'pro-debtor' regimes like the US; see 'Resolving' at 31. Interestingly, only in Sweden -- which also has a floating charge -- is the rate of 'going concern' sales higher; see Cycle at 3 and 'Resolving' at 31.

${ }^{153}$ And for this to be a fairness-based test, both the benefit of an increased chance of rescue, and any additional harm which results from the secured creditor's hold over the firm, would have to be measured from an appropriate perspective. This author has suggested elsewhere this perspective is best 
it is submitted the Franks-Sussman study cannot be used in support of either of the antisecurity Hypotheses. This suggestion is reinforced by the important fact that, as discussed above, the study shows secured creditors (in particular, the very bank whose strategy is discussed in this Section) seem to price their debt in a way which very clearly belies the assumptions and predictions of them both.

But do we have to leave this debate in this rather inconclusive state? Must we wait till data is available to decide the questions just posed, before deciding whether the priority of secured credit is desirable, all things considered? Fortunately, we can do somewhat better.

\section{Beginning the affirmative case for the priority of secured lending}

The burden of the argument so far has mostly been to show what security does not do. It has been argued it does not facilitate the exploitation of involuntary or 'uninformed' creditors. Nor does it create inefficiency through its ability to transfer insolvency value from 'nonadjusting' to secured creditors and debtors. It would be natural at this point to ask what its role really is. That debate seems interminable, as mentioned above. The issue will not of course be settled here. However, this Section takes the argument further, utilising evidence from this jurisdiction to suggest the priority of secured credit, by reducing the probability of the debtor's insolvency in the first place, is likely in general to be universally valueenhancing. The argument, in outline, is the following. Companies borrow on a secured basis in two situations. There are, first, those which could borrow without offering security. These companies have strong incentives not to offer security. They will pledge collateral only when this significantly reduces their risk of insolvency. Other companies are faced with the choice between either offering security, or not being able to borrow at all. This being the case, security is almost always offered for 'new money'. For such companies, this new money means the difference between solvency and insolvency. All creditors, including preferential, trade, and any 'involuntary' creditors, are far better off if their company survives, than if it is liquidated insolvent. It follows that secured credit, by improving the probability of the debtor's survival, is value-enhancing from their perspective in both situations. ${ }^{154}$

In the first situation, then, we should begin by noting that companies in a position to borrow on an unsecured basis have very strong incentives not to borrow secured. Evidence (from this jurisdiction and the US) that the strongest companies very rarely (if ever) borrow on a secured basis has already been mentioned above. ${ }^{155}$ As noted there, this fact is universally acknowledged, including by the leading critics of security. Nor is this some unexplained empirical anomaly. We have strong theoretical reasons for supposing firms would rather borrow unsecured than secured. We can understand these by first asking why firms issue secured debt. The only reason routinely mentioned is that it would allow them to benefit from reduced interest rates. But on this basis, the healthiest firms have little incentive to issue secured debt. This is because the reduction in interest rates that security supposedly

captured by the 'choice position' of the Authentic Consent Model, where a party is asked to make decisions about appropriate rules after being deprived of the knowledge, not only of whether it would be a trade creditor of a firm which is successfully rescued or of one which is liquidated, but even whether it will turn out to be a trade- or employee- or bank creditor in the first place, etc.; see Mokal, above $\mathrm{n} 2$.

${ }^{154}$ This argument is adapted from Schwarcz's compelling analysis in the US context; see above n 10.

${ }^{155}$ In the case of such companies, security would be offered only for non-recourse loans, where the lender's rights of recovery are limited to the asset or project being financed. It is obvious that here, the overall credit-worthiness of the borrower matters much less than the riskiness of the project itself. So when applied in this context, the arguments which follow should be interpreted as referring to the viability of the particular project being funded thus, not to the overall viability of the firm. 
brings is said to be overwhelmingly dependent on the probability of default on the loan. ${ }^{156}$ Now, the healthier the firm, the less likely it is to default. It follows that the healthier the firm, the less appreciable will be the interest rate difference for it to borrow on a secured basis, and the smaller the incentive for it to do so. ${ }^{157}$ Healthy firms would only borrow secured (rather than unsecured) in order to benefit from such differences if the benefit from doing so still outweighed the costs.

We should remember, though, that there are costs associated with secured debt, and that these can be substantial. Three of the most important categories of such costs are identified here. First, as emphasised above, the creditor with security has a far greater influence on debtor behaviour than the same creditor without, and it can demand more scrupulous compliance with loan covenants. The debtor's managers lose their freedom of action by issuing security, and with it, their ability to add to the variance of the firm's returns and thus to its shareholder value. Now there is of course a partial asymmetry in the way this loss is viewed by the debtor's shareholder-managers, and by all others interested in the debtor's undertaking. It has been noted time and again that controlling these agency costs is value-enhancing for the latter, because lowering the variance of the firm's returns also lowers the chances that it will be rendered insolvent. However, the shareholder-mangers, who would capture the upside from the additional variance, would consider the security-holder's ability to prevent them doing so as a reason against granting security.

Second, firms would prefer to keep unpledged collateral at their disposal till they really are in financial distress. The reasons for this have also been touched upon above. Distressed firms find it harder to persuade creditors to lend, since the latter perceive the high risk of default. Given that degree of risk, even critics of security accept that 'the interest rates necessary to compensate [lenders on an unsecured loan would be] far above customary and legal levels [more accurately, as already explained, above levels where the adverse selection and moral hazard problems associated with high rates become acute]. Creditors [would not then] charge higher rates; they [would simply] refuse to lend. ${ }^{158}$ It follows that 'existing firms with unpledged security are more likely to have access to external finance to help them trade through difficulties' by only then offering their assets as collateral. ${ }^{159}$ In addition, firms with growth possibilities would wish to keep free collateral in order to avoid the 'underinvestment' problem. They might find it difficult at a later date to finance a profitable project using outside funds, given that if insolvency then occurs, the returns from the new venture might go in part or fully to pay off pre-existing creditors. Being asked to subsidise these creditors in this way puts off potential new lenders from providing funds. The ability to attract new funding by offering later creditors a higher priority is one way of overcoming this problem. ${ }^{160}$ In both the situations just mentioned, 'using up' collateral prematurely, when it was still possible to borrow unsecured, merely to enjoy any tiny (more likely, non-existent) interest rate benefits would make little sense, and certainly would not be a rational strategy.

\footnotetext{
${ }^{156}$ See eg Finch,above n 11 at 638-9: 'The rational creditor will set the difference in rates after calculating the extra risk of non-repayment that a lack of security brings.'

${ }^{157}$ Finch herself notes this ibid at 639 , but does not seize on the implications for her argument which are drawn out here.

${ }^{158}$ This comes from LoPucki himself, above $\mathrm{n} 1$ at 1935, fn 181. This factor is of course crucial in the second of the two situations where security is deployed, and is further discussed below.

${ }^{159}$ BoE, above $\mathrm{n} 88$ at 26, including fn 32. See also Schwarcz, above n 10 at 450, including fn 102 (explaining the parallel notion of 'financial slack', familiar in the finance literature).

${ }^{160}$ See the classic Myers 'The determinants of corporate borrowing' (1977) 5 J. Financial Economics 147. For a useful recent discussion in the bankruptcy context, see Triantis 'Financial slack policy and the laws of secured transactions' (2000) 29 J. Legal Studies 35.
} 
Finally, and following from the observations above that strong companies do not often borrow on a secured basis and that any security-based interest rate differences are only going to be important for risky firms, encumbering most of one's assets could be a signal that creditors do not consider this debtor a safe enough risk to lend to it unsecured. ${ }^{161}$ We have already considered evidence above that in this jurisdiction, when creditors' perception of the firm's riskiness increases, the interest rate charged on loans to it goes up, and the firm's shareholder-managers are often asked to provide personal guarantees. Other counter-parties might also seek to tighten up their terms, insisting for example on trading on a cash-ondelivery basis. Once again, then, pledging the firm's assets is unlikely to be taken lightly by its managers, since it brings disadvantages both for them and their firm.

For all these reasons, firms able to borrow unsecured will only offer security where there is a significant ex ante risk of managerial misbehaviour, and therefore a significant risk of insolvency. Only then would the existence of security lower the risk of insolvent liquidation sufficiently to cause the lender to offer a rate reduction on a secured loan large enough to outweigh these costs. The most obvious example of the sort of firm in this position would be one with large growth potential, whose managers might be perceived to have a greater incentive, once the loan has been made, to engage in negative net present value projects. Managers could use security as a bond to obtain cheaper finance. ${ }^{162}$

Moving on to the second situation where security will be deployed, there is substantial evidence that for many of the companies borrowing secured, the choice is one between doing so and not being able to borrow at all, not that between borrowing unsecured on higher rates and secured on lower ones. The Bank of England has noted that 'Ready access to finance when needed is often a more compelling consideration for small firms than its actual cost', and that 'the availability of debt finance to small firms is affected by the size and value of those assets which can be taken as collateral'. ${ }^{163}$ A survey of its members by the Institute of Directors found that more than half of those 'whose plea for finance had been dismissed by their bank attributed the bank's decision to their lack of collateral' ${ }^{164}$ And we have already noted above that the Franks-Sussman study found that firms which eventually ended up in the banks' 'rescue units' had almost universally borrowed on a secured basis. In view of the evidence discussed above, any suggestion these firms could have bargained with their bank to borrow unsecured by offering a higher interest rate would be simply incredible.

This analysis leads us to postulate that there will come a time when some companies wishing to gain credit will either have to offer their assets as collateral, or do without credit altogether. Not all firms will then offer security; some would prefer to find other ways of

\footnotetext{
${ }^{161}$ See Schwarcz, above n 10 at 446, including the references in fn 93. This will of course not be the case in markets where security is ubiquitous.

162 This is consistent with UK evidence; see Lasfer, 'Debt structure', pp. 15-6: 'firms with high growth opportunities are likely to use leasing, [and] secured debt', and that 'growth opportunities are not financed with subordinated loans, [or] unsecured... debt'. Lafer also points out that larger firms, even if they have high growth potential, are less likely to offer security.

${ }^{163}$ See BoE, above $\mathrm{n} 86$ at 25 and 26 (footnote omitted).

${ }^{164}$ Wilson, Bank Finance (2000) at 4, 13 and 15. That collateral was perceived to be so important to the banks' lending decisions was in fact one of the leading complaints by the respondents; see p. 12. It must be kept in mind, however, that almost two-thirds of the same set of respondents reported they had never been refused extra finance by their bank, and that this was true for $77 \%$ of those who considered their firm to be involved in high technology (a sector where firms generally have little collateral to pledge). Tellingly, none of the respondents whose request for funding had been turned down by the bank felt the reason was that they themselves had a poor business plan! See ibid at 12-3. Members of the Federation of Small Businesses were somewhat more successful in obtaining finance; $72 \%$ of them have never been refused finance by their bank; see FBS, Small Businesses' Finance and the Economy: Survey of FSB Members (1998) at 87.
} 
raising money (e.g. through equity injections), or would go without additional funds at that point. ${ }^{165}$ So for firms which do end up borrowing on a secured basis, the choice they would have faced would likely have been even starker. It would have been one between offering security or going into insolvent liquidation. The reason is easy to understand. Firms would only borrow on a secured basis when they could not borrow unsecured, and the value to them of new funding exceeded the costs identified above. This is only likely to be the case when they face a serious threat to their continued survival. Only then would the opportunity cost of having unpledged assets (held precisely so as to be available in a crisis), any reputational costs of offering security, the costs of surrendering some freedom of action to a creditor, etc. are likely to be outweighed by the expected costs of impending insolvency. We can speculate about the type of company likely to find itself in this situation. Most obviously, this would be the case for companies on the brink of or already in financial distress. It is also likely to be the case with some start-ups which have no established track record and therefore a lesser chance of persuading a bank of the competence of its management and (less importantly) the viability of its business plans. ${ }^{166}$ Both types of firm are likely to be faced with a credit crunch and a looming liquidity crisis. And there is support for the proposition that the lack of liquidity is a leading cause of insolvency. ${ }^{167}$ Loss of long term finance, lack of working capital and a poor cash flow have been consistently identified as among the main factors in company failure in successive Surveys by the Association of Business Recovery Professionals (formerly, SPI). ${ }^{168}$ And the Bank of England has noted the more direct finding that 'the availability of collateral does not impact on the birth of new firms, but on [their] survival rates' ${ }^{169}$

So firms unable to borrow without pledging collateral are likely to borrow secured only when their survival depends on being able to find fresh funding. This should be read together with evidence from the US that the availability of fresh funding for distressed firms raises both the expected recovery rates for unsecured creditors, and the chances of the firm itself being rescued successfully. ${ }^{170}$ We can now see why the availability of secured funding is actually value-enhancing for all of the firm's creditors. All creditors are much better off if their debtor either (a) lowers the probability of ending up insolvent, or even more strongly, (b) recovers from financial distress. This is dramatically brought out by considering the following calculation. ${ }^{171}$ Let $U=$ the expected value of unsecured claims, $p=$ the probability that the debtor would be liquidated insolvent, and $\mathrm{F}=$ the actual, full value of unsecured claims. Suppose also that if the debtor is liquidated without secured credit ever being issued, unsecured creditors would get a (very generous) 80 pence on the pound. ${ }^{172}$ If the debtor becomes insolvent after having issued secured credit, unsecured claimants would (pessimistically) get nothing. ${ }^{173}$ In either case, if the debtor survives, unsecured creditors are paid back in full. Finally and in line with the analysis above, assume that if secured credit is

\footnotetext{
${ }^{165}$ Remember that during the $1997-9$ period, $60 \%$ of SMEs did not seek any external finance at all; see Bank of England, Finance for Small Firms: An Eighth Report (2001) at 23.

${ }^{166}$ Association of Business Recovery Professionals (or ABRP), Survey of Business Recovery in the UK: 9th. Survey (2001) (hereafter, 9th. Survey) at 7, provides evidence that younger firms are 'far more prone to failure than established businesses'.

${ }^{167}$ See the illuminating discussion in Schwarcz, above n 10 at 445-9, including fnn 87, 102 and 104.

${ }^{168}$ See 9 th. Survey at 13.

${ }^{169}$ BoE, above n 86 at 26.

${ }^{170}$ See the interesting paper by M. Carapeto, 'Does debtor-in-possession financing add value?' (Unpublished, 2001). The reader should also recall that $75 \%$ of firms in the banks' 'rescue units' are successfully turned around.

${ }^{171}$ Adapted from Schwarcz, above n 10 at 473-4.

${ }^{172}$ The generosity of this figure can be judged from the fact that it is higher than the average of $77 \%$ that secured creditors presently get; see Cycle at 3.

${ }^{173}$ This is pessimistic because the figure covers preferential creditors, who currently get an average of around $27 \%$; see ibid at 3 .
} 
not available when it is most likely to be used (i.e. when the debtor suffers a high risk of ending up insolvent), the probability of the debtor being liquidated insolvent is (a relatively low) $60 \%$. If secured credit is then issued, it falls moderately to $40 \% .{ }^{174}$ The expected value of unsecured claims is then given by the equation:

Expected value of unsecured claims $=$ probability of insolvent liquidation multiplied by the return on unsecured claims in debtor's insolvency + probability of rescue multiplied by the return on unsecured claims if debtor is rescued.

If no secured debt is issued, the equation can be solved as follows:

$$
\begin{aligned}
& \mathrm{U}=\mathrm{p}(0.8 \times \mathrm{F})+(1-\mathrm{p}) \mathrm{F} \\
= & 0.6(0.8 \times \mathrm{F})+(0.4 \times \mathrm{F}) \\
= & 0.52 \times \mathrm{F}
\end{aligned}
$$

On the other hand, if secured debt is issued, the outcome is:

$$
\begin{aligned}
& \mathrm{U}=\mathrm{p}(0)+(1-\mathrm{p}) \mathrm{F} \\
= & (0.4 \times 0)+0.6 \times \mathrm{F} \\
= & 0.6 \times \mathrm{F}
\end{aligned}
$$

So even on these very conservative figures which assume a relatively low probability of insolvent liquidation if the high-risk firm does not borrow on a secured basis, a very moderate decrease in this probability if secured credit is issued, and fairly extreme figures for the return on unsecured claims, the conclusion is still that all unsecured creditors are better off because some creditors are induced to lend by being offered priority, when they would not lend if priority could not be offered to them. So secured credit enhances the expected value of all claims (preferential, trade, involuntary, 'uninformed', 'non-adjusting', etc.) by reducing the risk of the debtor's insolvency.

It should also be pointed out that this argument does not depend at all on many of the 'traditional' justifications of security, e.g., that it is fair from the point of view of unsecured creditors because they would have notice of its existence, or that the law should not restrict the property rights of debtors in their assets or the freedom of contract of debtors and potential secured creditors. ${ }^{175}$ Nothing in this argument turns on taking any position on these issues.

There is however one other possibility which has not yet been considered. Suppose the debtor has no secured debt, and gets into difficulties. Its main bank demands security, not by offering it more credit (or sufficient credit to bring about an improvement in the debtor's chances of survival we stipulate to be 'appropriate'), but by threatening to send it into liquidation straightaway if security is not given for debt already outstanding. It would be very

\footnotetext{
${ }^{174}$ It should be obvious these figures are very severe indeed towards the argument being made. The eventual conclusion would be even clearer if the probability of failure without credit was assumed to be higher, or the improvement in that probability greater if secured debt was issued, or both.

${ }^{175}$ See eg Finch, above n 11 at 660-3.
} 
surprising if this never happens in the real world today. ${ }^{176}$ This is the point where the analysis in this Section ties into the suggestions made at the end of the previous one. It is in the situation now being considered that the only benefit (if any) to the debtor's unsecured creditors comes from the increased ability of the bank to monitor and influence the debtor, thereby improving the latter's chances of recovery. So the two questions given at the end of the last Section are relevant only to that sub-set of situations where security is given for no (or insufficient) new value.

However, we should note the following point. Even if it were concluded, in this situation, that the expected costs to unsecured creditors of being deferred to secured creditors in their debtor's insolvency are greater than the expected benefits of the improved chances of avoiding insolvency flowing from the increased control of debtor behaviour alone (as explained in the previous Section), this still would not by itself be an argument for restricting the priority of secured lending. We would then have reason to suppose priority was being demanded by one creditor here simply to improve its own position at the expense of others, in other words, to secure a preference for itself. But then, this ought to be dealt with just like any other attempt to engineer such a preference. So we would have an argument for strengthening the legal provisions against voidable preferences (and perhaps those against transactions at an undervalue), so as to bar the offering of security except for appropriate new value. In effect, there would then be a good reason for reconsidering -- and perhaps reversing -- either or both parts of the decision in Re MC Bacon Ltd. (No. 1). ${ }^{177}$ An obvious reform would be to extend in an appropriate way the effect of section 245 of the Insolvency Act, which invalidates floating charges granted for 'past value', to cover fixed charges as well. It seems to this author that any more general tampering with the priority of secured credit needs stronger justification than is currently available.

\section{Conclusion}

This paper has examined the main attacks on the institution of secured credit, and in particular, on the priority of secured lending. It identified the main parties that are alleged to be harmed by the existence of that priority. The supposed exploitation of involuntary (especially tort) creditors was the obvious starting point. It was argued that the possibility of such exploitation is very remote. For large firms which have the ability to acquire significant involuntary credit (for example by inflicting tortious harm), there is evidence that little or no secured debt is issued, and such involuntary creditors are paid off to a significant degree. For smaller firms which do issue security, the alleged benefit of reduction in interest rates obtained by doing so is likely to be greatly outweighed by the costs of liquidation to their shareholder-managers. A 'representative' numerical example was discussed in order to bring out the implausibility of the Exploitation Hypothesis. Empirical data was also examined to test the predictions of the Hypothesis, each one of which it seems to contradict.

Attention was also given to the claim that security creates a subsidy extracted by coalitions of debtors and secured creditors from 'uninformed' or 'ill-equipped' or 'unsophisticated' creditors who systematically underestimate the risk associated with their

\footnotetext{
${ }^{176}$ At the same time, however, it would be quite astounding if this were the only or dominant situation where security was demanded and offered, so that secured credit rarely improved the debtor's chances of recovery.

${ }^{177}$ [1990] BCC 78. The two parts referred to are the propositions that, first, the giving of security for past value can never constitute a transaction at an undervalue for the purposes of $\mathrm{s} 238$ of the Insolvency Act, and second and more directly tied to the statutory language itself, that there is no voidable preference for the purposes of s 239 of the Act unless the debtor is motivated by a 'desire' to prefer the creditor to whom security is granted.
} 
loans and therefore under-price them. Such arguments seem to pay insufficient attention to the purging effects of the market, which encourage creditors either to learn how to price loans properly, or be driven out of business. The startling implications of the suggestion that naturally 'unsophisticated' creditors be 'protected' from the effects of the priority of secured credit were also brought out and examined.

The claims that the existence of 'non-adjusting' creditors leads to several types of inefficiency, mainly to do with the monitoring implications of substituting the protection it offers in place of the extraction and enforcement of non-security covenants, were also investigated. It was suggested that empirical evidence from this jurisdiction casts doubt both on the assumptions on which these arguments (and the others noted above) are based, and on the predictions that can be extracted from them. Most notably, the assumptions that it is up to the debtor to offer security, and that if it does, the interest rate it is charged would go down while the insolvency costs of its shareholder-managers remain unaffected, all are found to be false. The basic prediction of the anti-security Hypotheses that there would either be no significant relationship, or a direct one, between the proportion of the total estate derived from value provided by the secured creditor and the interest rate it charges, is also strongly belied by the evidence available. In this context, the informal 'intensive care' provided by banks (generally as secured creditors) to distressed firms was also examined.

In view of all these arguments and data, we can conclude, as did Schwartz in the US, that in this jurisdiction too, 'the case for restricting the secured debt priority in bankruptcy has yet to be made. ${ }^{178}$ The argument in this paper concluded with a demonstration that the priority of secured credit is likely to be value-enhancing for all unsecured creditors. To the extent that this last point holds, unsecured creditors have every reason to wish not to be 'saved' from secured ones!

\footnotetext{
${ }^{178}$ Schwartz, above n 113 at 1398.
} 
